\title{
REVIEW
}

\section{Respiratory health effects of man-made vitreous (mineral) fibres}

\author{
P. De Vuyst*, P. Dumortier*, G.M.H. Swaen**, J.C. Pairon+, P. Brochard"\#
}

Respiratory health effects of man-made vitreous (mineral) fibres. P. De Vuyst, P. Dumortier, G.M.H. Swaen, J.C. Pairon, P. Brochard. CERS Journals Ltd 1995.

ABSTRACT: The group of man-made mineral or vitreous fibres (MMMFs or MMVFs) includes glass wool, rock wool, slag wool, glass filaments and microfibres, and refractory ceramic fibres (RCFs).

Experimental observations have provided evidence that some types of MMVF are bioactive under certain conditions. The critical role of size parameters has been demonstrated in cellular and animal experiments, when intact fibres are in direct contact with the target cells. It is, however, difficult to extrapolate the results from these studies to humans since they bypass inhalation, deposition, clearance and translocation mechanisms. Inhalation studies are more realistic, but show differences between animal species regarding their sensibility to tumour induction by fibres. Fibre biopersistence is an important factor, as suggested by recent inhalation studies, which demonstrate positive results with RCF for fibrosis, lung tumours and mesothelioma.

There is no firm evidence that exposure to glass-, rock- and slag wool is associated with lung fibrosis, pleural lesions, or nonspecific respiratory disease in humans. Exposure to RCF could enhance the effects of smoking in causing airways obstruction.

An elevated standard mortality ratio for lung cancer has been demonstrated in cohorts of workers exposed to MMVF, especially in the early technological phase of mineral (rock slag) wool production. During that period, several carcinogenic agents (arsenic, asbestos, polycyclic aromatic hydrocarbons (PAH)) were also present at the workplace and quantitative data about smoking and fibre levels are lacking. It is not possible from these data to determine whether the risk of lung cancer is due to the MMVFs themselves. No increased risk of mesothelioma has been demonstrated in the cohorts of workers exposed to glass-, slag- or rock wool. There are in fact insufficient epidemiological data available concerning neoplastic diseases in RCF production workers because of the small size of the workforce and the relatively recent industrial production.

Eur Respir J., 1995, 8, 2149-2173.
*Chest Dept, Hôpital Erasme, Université Libre de Bruxelles, Brussels, Belgium. **Dept of Epidemiology, University of Limburg, Maastricht, The Netherlands. ${ }^{+}$Service de Pneumologie et de Pathologie Professionnelle et Environnementale and INSERM Unité 139, Centre Hôspitalier Intercommunal, Créteil, France. "Université Bordeaux II, Bordeaux, France.

\author{
Correspondence: P. De Vuyst \\ Chest Department \\ Hôpital Erasme \\ Route de Lennik, 808 \\ B-1070 Brussels \\ Belgium \\ Keywords: Animal models \\ asbestos \\ epidemiology \\ in vitro \\ lung cancer \\ lung fibrosis \\ man-made vitreous fibres \\ mesothelioma
}

Received: February 221995

Accepted after revision June 121995
Triggered by the partial asbestos ban, a range of substitute products have been and are still being developed. Manufactured (artificial) fibres represent an important and continuously growing volume among these substitutes. More than 70 varieties of synthetic inorganic fibres are produced, covering over 35,000 different applications. Glass wool, rock wool, slag wool (all three referred to as insulation wools), glass filaments and microfibres, and refractory ceramic fibres $(\mathrm{RCF})$ constitute the group of man-made mineral or vitreous fibres (MMMF or MMVF). In an industrialized society, a major proportion of the population has been, is, or will be in contact with these fibres.

By reference to their physical characteristics, there is great concern about the potential health risks resulting from exposure to MMVFs. Several issues have enhanced interest in the potential health risks that could be associated with the use of MMVFs. The term "mineral fibre" evokes similarities with naturally occurring fibres (asbestos, erionite), which are the cause of various benign and malignant diseases. As the fibrous configuration of asbestos is an important parameter in toxicity, the synthetic fibres are also suspected of inducing serious health effects on the respiratory system. Moreover, some of the uses and applications of MMVF and asbestos are very similar.

In 1988, the International Agency for Research on Cancer (IARC) published a monograph in which insulation wools were categorized as $2 \mathrm{~b}$, and thus possibly carcinogenic to humans [1]. This was based largely on the results of animal experiments. Since then, MMVFs have been subjected to a variety of in vivo and in vitro tests to determine if they really are carcinogenic or fibrogenic. 
Although asbestos toxicity is not the subject of this paper, it is useful firstly to consider some "key words", emerging from the asbestos literature. Indeed, fundamental knowledge about the parameters and mechanisms that influence the toxicity of mineral fibres is derived from the asbestos experience.

\section{Fibre inhalation and deposition [2, 3]}

The primary characteristics necessary for particles to induce respiratory disease is to be inhaled, deposited and retained in the respiratory tract. For mineral fibres, the determinants of penetration and deposition in the airways are the aerodynamic diameter (which is roughly three times the physical diameter for fibres shorter than $100 \mu \mathrm{m})$ and the fibre length.

Asbestos fibres or fibres with the same density are considered to be respirable for humans when they have physical diameters less than 3-3.5 $\mu \mathrm{m}$ (corresponding to an aerodynamic diameter of less than $10 \mu \mathrm{m})$.

\section{Biopersistence (durability in biological tissues) [4-7]}

Experimental data clearly indicate that fibres that are difficult or impossible to eliminate by the pulmonary clearance mechanisms, and that are not subject to physical breakdown or chemical dissolution, are more likely to exert their bioactive effects and are, thus, potentially more fibrogenic and carcinogenic.

Studies involving measurements of asbestos fibres in lung tissue or lung lavage fluid from humans or experimental animals have demonstrated that the long-term retention is greater for amphiboles than for chrysotile.

Epidemiological data consistently indicate that the incidence of malignant mesothelioma and excess of lung cancer are much higher in the cohorts exposed to amphiboles or mixtures (amphiboles/chrysotile) than to chrysotile alone.

\section{Physicochemical parameters}

Dimensions [8, 9]. A fibre is a particle with a length/ diameter ratio of $\geq 3 / 1$ and roughly parallel edges. The intrinsic toxicity of fibres is dependent on their length (L), diameter (D) and aspect ratio (L/D): experimental evidence by intrapleural and intraperitoneal studies has demonstrated that the most carcinogenic fibres for the mesothelium have lengths over $8 \mu \mathrm{m}$ and diameters less than $0.25 \mu \mathrm{m}$.

Physicochemical structure and surface properties [10, 11]. The crystalline structure influences the toxicity of particles of similar chemical composition. In this respect, quartz and cristobalite (two varieties of crystalline silica) are more fibrogenic than amorphous silica.

According to several hypotheses, the production of oxygen radicals could be an important step in fibrogenesis and carcinogenesis. The surface oxidizing properties depend largely on the nature of the fibres.

\section{Translocation [12, 13]}

Once fibres are deposited in the lung, they can be transported from the deposition zones (respiratory bronchioles, alveoli) to other target organs. The mechanisms and pathways of the translocation of asbestos fibres towards the pleura, and particularly the parietal pleura, from which mesothelioma and pleural plaques seem to develop, are still a matter for research.

\section{Dose [14-17]}

This is also a complex concept when considering fibres. The "external" dose is usually expressed as number of fibres. $\mathrm{mL}^{-1}$ or $\mathrm{m}^{-3}$ air, or even as a cumulative dose, expressed as fibres $\cdot \mathrm{mL}^{-1}$ multiplied by duration of exposure (fibre-years).

However, the amount of fibres deposited by inhalation is much less than the amount of fibres estimated from cumulative dose of exposure. Depending on the inhalation and deposition and the biopersistence of the fibres, an "internal" dose will remain, that can be expressed as the number of fibres. $\mathrm{gm}^{-1}$ of dry lung (biometrology, mineralogical analysis).

Asbestosis (lung fibrosis) is usually associated with high concentrations of fibres in lung tissue resulting from heavy and/or prolonged exposures.

Despite the fact that a dose-relationship has been demonstrated for mesothelioma, this disease has been associated with short or low dose exposures, as well as with low concentrations of fibres in lung tissue.

\section{Latency periods [6, 18, 19]}

It is important, from a clinical point of view, to keep in mind that fibre-induced neoplastic diseases manifest themselves several decades after the onset of exposure, up to $50 \mathrm{yrs}$; the mean latency of mesothelioma is about 35 yrs.

\section{Cigarette smoking [20-22]}

Epidemiological studies have shown a synergistic effect between smoking and asbestos exposure (multiplicative rather than additive effects) in causing lung cancer. However, an increased risk has also been reported in nonsmokers, and the asbestos/smoking interaction in lung cancer is not yet quantified.

Smoking also appears to influence the development of lung fibrosis (asbestosis). This could be due to inhibitory effects of cigarette smoking on pulmonary clearance mechanisms and enhancement of asbestos penetration of respiratory epithelium.

Mesothelioma is unrelated to smoking. 
Asbestosis and lung cancer [23-25]

The respective roles of asbestosis and asbestos burden in the pathogenesis of cancer associated with asbestos exposure is still a matter of debate. The great majority of asbestos-exposed workers with bronchial carcinoma have radiological or pathological evidence of interstitial fibrosis. It is possible that both diseases are related, the cancer being a result of longstanding parenchymal inflammation and fibrosis. It is also possible that the coexistence of asbestosis and lung cancer merely reflects the expression of two diseases with a similar dose-effect relationship. Recent data suggest that asbestos could also be associated with lung cancer without radiological signs of lung fibrosis.

The aim of this review is to summarize the current knowledge about the respiratory toxicity of MMVFs. The different types of MMVF will be defined, and the results of toxicity testing by means of in vitro studies, injection and inhalational studies in animals will be presented. The epidemiological and clinical data in humans occupationally exposed to MMVFs will also be summarized and discussed.

\section{Definition and classification of MMVF}

Classifications based on the chemical composition of the fibre, its mean diameter and diameter distribution in the product, include numerous MMVF types. In this chapter, we will first define various aspects of MMVF classification and properties that may be relevant when examining their potential health effects. Most of the information in this chapter is derived from the key references [1, 26, 27]. The factors influencing the fate of those fibres in the biological environment (biopersistence) are also reviewed. Finally, general occupational and environmental hygiene data are reported.

\section{Terminology (man-made fibre (MMF)/MMMF/MMVF/} $R C F$ )

Until the Thermal Insulation Manufacturers Association (TIMA) [26] proposed a restrictive classification of MMVF, the terminology of manufactured (synthetic) fibres was not well defined. The following scheme (table 1) takes into account the various conventions that were used for some terms in earlier documents. TIMA classification is limited to vitreous silicate fibres, including the common purpose insulation wools, which represent more than $80 \%$ of the total production of MMVFs, glass continuous filaments, glass microfibres and vitreous silicate ceramic high temperature (refractory) insulation fibres. Although all ceramic fibres are used in high temperature insulation, TIMA propose to exclude crystalline and nonsilicate fibres from the definition of RCFs. The previously published definitions by the International Programme on Chemical Safety (IPCS)/IARC [1, 27] for MMMFs also include nonsilicate and crystalline fibres, which represent a small proportion of the total production of synthetic fibres and cover very specialized applications; populations exposed to these fibres are small and data about their potential toxicity are scarce.

From an industrial point of view, essentially related to their manufacturing process, fibre diameter and final use, MMVFs are also broadly categorized according to the following subdivisions: continuous filaments; insulation wools; special purpose glass microfibres; and refractory ceramic fibres. From a toxicological point of view, and according to the European Union directives concerning protection of man at work [28], it is important to distinguish: 1) fibres considered as substances that may be released in the atmosphere at any step of the manufacture or use of commercial products; 2) fibre containing products considered as preparations, and that may contain different types of fibres or other substances (resin, cement, other minerals). In this sense, fibres considered

Table 1. - Nomenclature of man made fibres

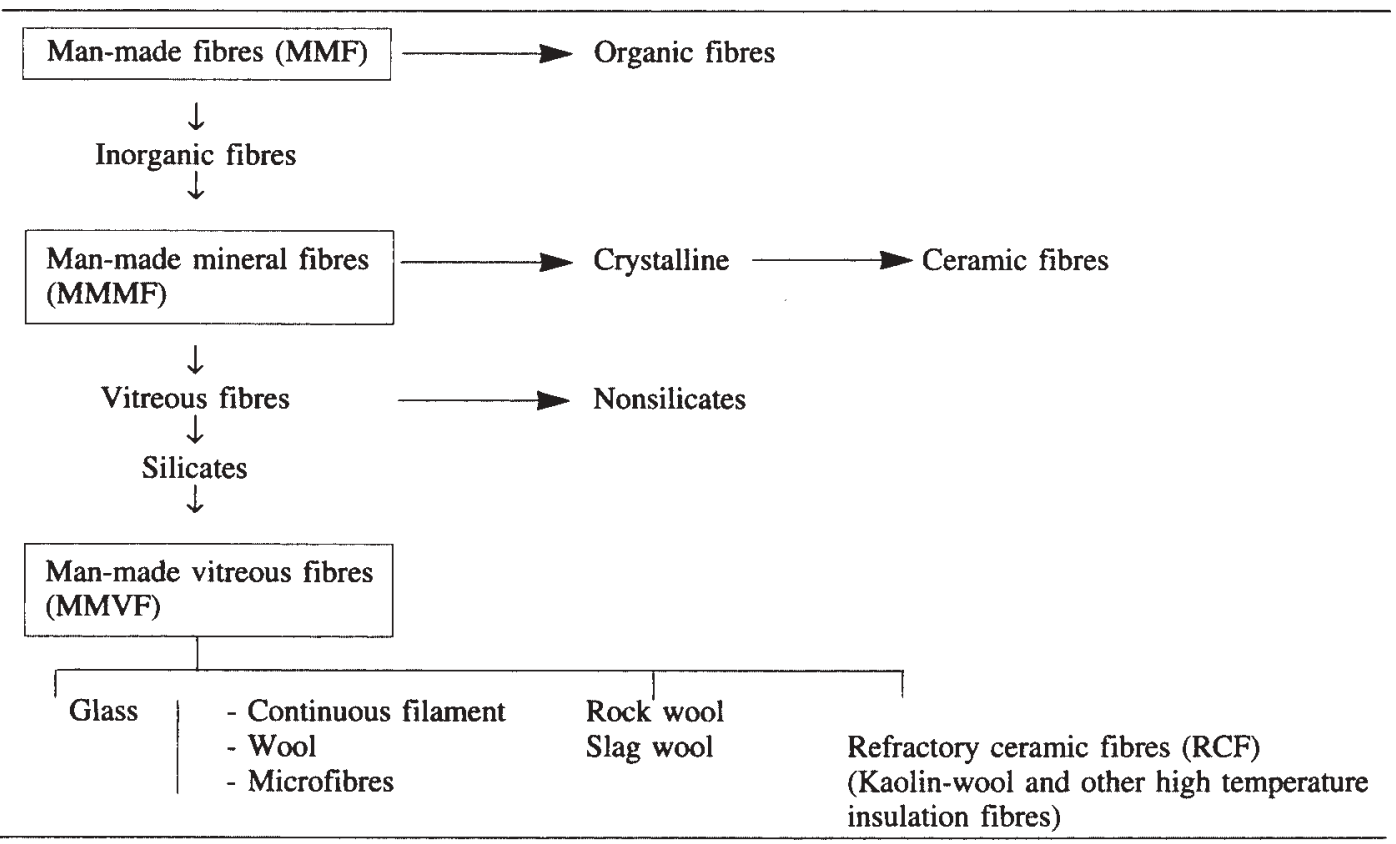


as substances should be defined according to their chemical composition: different types of glass, rock, slag and ceramic fibres. As the precise mechanisms of fibre toxicity are not yet understood, grouping of fibres of equivalent potential toxicity is not yet complete.

\section{Production of MMVFs}

MMVFs are manufactured from molten glass, rock, slag, kaolin clay or combinations of silicon and aluminium oxide. Depending on the raw material used, the melting temperature ranges $1,000-1,500^{\circ} \mathrm{C}$ for glass fibres, rock- and slag wools, and $1,800-2,000^{\circ} \mathrm{C}$ for the most common RCF. Three basic processes are used to produce fibres from the molten material. Fibres may be produced by mechanical drawing of extruded threads of molten material, as is the case in the production of continuous filament glass fibres. The two other basic processes are designed for the fabrication of "wool"-like products. In contrast to the more ordered fibres in continuous filament glass, a "wool" is an entangled mass of fibres without any ordered arrangement [29]. This type of fibre may be generated by blowing droplets or threads of molten material into jets of steam, hot air or in a flame, or by attenuation of droplets of liquid melts by centrifugation. Several combinations of these three basic processes are commonly used [26, 30]. During the process of fibre production, several additives, such as dust suppressing agents or binders, may be sprayed onto the raw fibres $[1,26,30]$.

\section{Chemical composition}

The chemical composition of the various types of MMVF depends directly on the raw material used to manufacture them and on the elements eventually added to meet some required properties, such as resistance to chemicals, tensile strength, high temperature resistance, or electrical properties. Continuous filament glass fibres, glass wool and glass microfibres are made from silicated glass, generally containing boron oxide added as a flux to lower the melting temperature of the raw material. Rock wool is made from igneous (basalt) or metamorphic (granite, slate and limestone) rocks [29]. Slags formed during the extraction of various metals from ores are used as raw material to produce slag wool. At present, only slag derived from iron blast furnace is used, but in the past slags from various origins, such as copper smelters, were used. RCF are manufactured from kaolin clay or from mixtures of pure silica and aluminium oxide. In all these processes, variation in chemical composition can occur within the same type of production, for fibres made of natural (sand, rock) or industrial (slag, reprocessed glass) materials. The range of typical chemical composition of the various types of MMVF is reported in Appendix I.

\section{Uses}

Continuous filament glass fibres are used as reinforcement of cement, plastics and resinous materials, in paper and rubber products, in the form of textiles, and in electrical insulation. They account for $10-15 \%$ of the total MMVF production. Glass-, rock- and slag wools represent more than $80 \%$ of the total MMVF production. They are used mainly for thermal and acoustic insulation, for fire protection (rock wool and slag wool), in acoustic ceiling tiles and panels, in the manufacture of air-conditioning and ventilation ducts, and as growing media for horticulture. RCFs represent $1-2 \%$ of the total MMVF production. The main applications of RCFs are in high temperature insulation of furnaces and kilns. Special purpose glass fibres represent less than $1 \%$ of the production. They are used for high efficiency thermal insulation (aircraft and aerospace), high performance acoustic insulation, high efficiency filtration, and as battery separator media.

\section{Thermal behaviour of $M M V F$}

Resulting from their use in insulation applications, MMVFs may be subject to occasional (e.g. building fires) or constant (e.g. blast furnace insulation with RCF) high temperatures. The thermal behaviour of the various types of MMVF is mainly determined by their chemical composition. Glass fibres will melt above $850^{\circ} \mathrm{C}$. Glass fibres do not recrystallize after melting. In contrast, rock- and slag wool devitrify and recrystallize above $850^{\circ} \mathrm{C}$. Above this temperature, pseudowollastonite and anorthite are formed, but no cristobalite. Concerning RCF, kaolinbased wools and wools obtained from 50:50 mixtures of aluminium and silicon oxides devitrify above, $1,000^{\circ} \mathrm{C}$ to form mullite and cristobalite.

Thus, from the occupational hygiene point of view, products having undergone thermal ageing either in normal use or incidentally must be considered separately from unaltered products.

\section{Additives and contaminants}

In order to reduce the release of dust during the production of MMVFs, to give coherence and to allow formation of the final product, several additives are usually sprayed onto the fibres during the process of fibre production. At this stage, antistatic, antifungal, fireretardant, hydrophobic or wetting agents may also be added, according to the desired properties of the product. These additives may represent as much as $25 \%$ of the weight of the final product. Mineral oil and polypropylene glycol are used as dust suppressing agents. Typical binders include formaldehyde resins, urea, epoxy resins, bitumens. RCFs are generally produced without coatings, but binders may be added to manufacture ceramic fibre felts [31].

The presence of several airborne contaminants or "byproducts" has been observed during the production of mineral wools, especially in the early production phases. In a realistic full-scale simulation of the working conditions prevailing at that time in a slag wool production plant, FALLENTIN and KAMSTRUP [32] have measured the emission of various air pollutants. They reported the 
release of significant levels of polycyclic aromatic hydrocarbons (PAH) and airborne particulates during MMVF production. Since this simulation demonstrates that even minimal concentrations of lead and zinc $(0.7$ and $0.09 \%$, respectively) in the raw slag material may result in very high concentration of these highly volatile metals in the airborne dust $(\mathrm{Pb} 10.2 \%$ and $\mathrm{Zn} 63.1 \%$ of total airborne dust), the authors postulate that the use of some arsenicbearing copper smelter slag in the past may have led to substantial arsenic exposure.

The presence of asbestos fibres, either as a contaminant of raw materials used in rock wool production or as a result of the parallel processing of asbestos containing products in some MMVF production plants [33, 34], is also described.

\section{Size characteristics of MMVFs}

The dimensional parameters of fibres are of utmost importance when considering fibre inhalation, lung deposition and toxicity. However, fibres in the aerosol or within products have different lengths and diameters. It is, thus, necessary to characterize the size distribution:

1. In aerosol or biological samples, each fibre is counted and measured after sampling on filters. It is then possible to report the mean diameter and length and their standard deviation. Due to a log normal distribution, geometric mean and geometric standard deviation are used. For purposes of industrial hygiene [35, 36], the total number of fibres longer than $5 \mu \mathrm{m}$ and with diameter less than $3 \mu \mathrm{m}$ are determined.

2. In products, diameter is the only useful parameter. Indeed, length will vary because of breakage during the different stages of use, without modification of diameter, as there is only transverse breakage and no longitudinal cleavage in MMVF.

The length-weighted median diameter is, thus, determined after mild crushing. The length of all the fibres of the sample are summed in order of increasing diameter, the diameter at the mid-point of the total length is the nominal diameter. It is easy to use for bulk MMVF materials, since it is completely independent of the extent of fibre fracture.

Diameter distribution and mean diameter of MMVF products depends on the compostion of the fibre and the

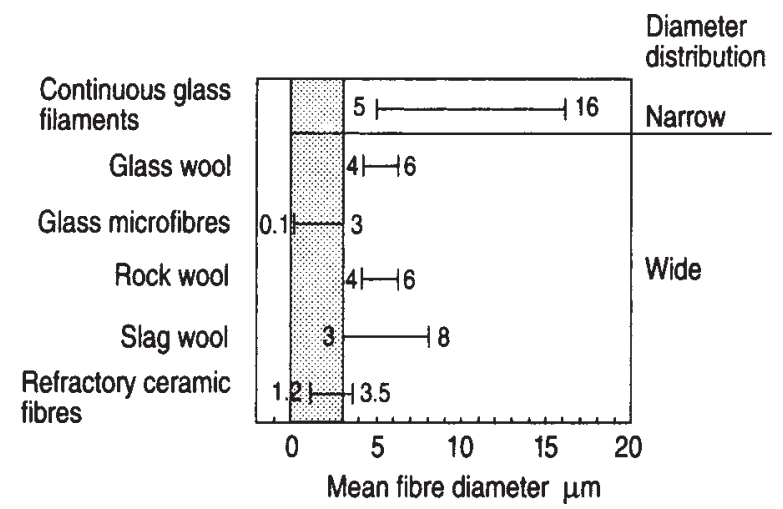

Fig. 1. - Mean fibre diameter and diameter distribution for typical MMVF products. $\because$ : range of diameter for respirable fibres. MMVF: man-made vitreous fibres. production process. Figure 1 gives an overview of the "mean" diameters reported in the literature for each type of product $[27,37,38]$

For continuous glass filaments, the diameter distribution is very narrow, all the fibres having approximately the same diameter. Resulting from the relatively wide diameter of these fibres and from the fabrication process (drawing), very few respirable fibres are produced. Insulation wool, RCF and special purpose fibres have a wider diameter distribution around the mean [30]. Fibres with diameter falling in the range of respirable fibres are produced in more or less high proportion [31].

\section{Historical background}

Appendix II is a historical review of the main steps in the production of MMVFs. The general evolution of the mean fibre diameter in the insulation wools is apparent. However, it must be noted that fibres with very small diameters were already present in some products manufactured in the very early production periods. A particular slag wool manufactured in 1928 was reported to contain $60 \%$ of fibres with a diameter less than $3 \mu \mathrm{m}$ [30]. Due to production changes of MMVF, between the 1930s and the present, the average nominal diameter of the products has decreased over the years [39]. The fibre distribution of the product has become concentrated about the mean as a result of the reduction in the largest fibre diameters, but with no change in the percentage of the smaller diameter fibres. The coarse fibres (the upper tail of the fibre distribution in the product) are undesirable, since they represent inefficiently used material, add unnecessary weight to the product, and are also believed to be responsible for most skin irritation caused by MMVFs [39].

The trend to decrease the fibre diameter in insulation wools and to produce microfibres is explained by the fact that the thermal and acoustic insulating coefficient increases when the fibre diameter decreases, products with finer fibres having better insulation coefficient. In filtration applications, filtration efficiency also increases with decreasing fibre diameter.

"Technological phases" are also presented in this Appendix II. The early technological phase is characterized by the use of batch (discontinuous) production processes and the absence of dust suppressing agents. In the late technological phase, a continuous production process and dust suppressing agents are used. Some plants went through an intermediate phase, during which a mixture of production types or techniques was used [27]. Since the notion of early and late technological phases are based on differences in the manufacturing process, the transition from early to late technological phase varies from plant to plant, according to the changes made in their production technology.

\section{Biopersistence of MMVF}

It is generally accepted that the pathogenic properties of mineral fibres are related to their accumulation and 
persistence under a fibrous configuration in target organs. Some intrinsic physicochemical properties of MMVFs greatly affect their durability in the biological environment. This is actually a major field of concern and research in the evaluation of MMVF toxicity, since it is unlikely that fibres that are rapidly cleared or dissolved in the lung would have time enough to exert the potential toxicity linked to their dimensions and fibrous shape.

Because of their vitreous microstructure, MMVFs do not split longitudinally like asbestos fibres, but break transversally. From this transverse breakage, fibres become shorter with the same diameter as the original ones. This is quite different from numerous fibres with smaller diameters but without change in length that occur with defibrillation of asbestos fibres [30]. MMVF breakage may be enhanced by the alterations in fibre chemistry that occur in vivo (see later). In vitro studies were performed to evaluate the solubility of various MMVFs in aqueous media at varying $\mathrm{pHs}$, in synthetic physiological fluid, and in fixatives currently used to preserve lung tissue samples. The solubility of MMVFs is evaluated from the mass loss of silica and other components measured in the leaching fluid. Roughly, these studies demonstrate that the solubility of MMVFs is positively associated with the concentration in alkali and earth alkali [40].

SCHOLZE and CONRADT [41] (1987) examined the network dissolution velocity of 10 types of MMVF and 3 types of natural fibres (chrysotile, crocidolite, erionite) in Gamble solution, and deduced a durability hierarchy in terms of lifetime for fibres of $1 \mu \mathrm{m}$ diameter. For six samples of glass, rock and slag fibre lifetime was shorter than or equal to $2 \mathrm{yrs}$, for RCFs around $5 \mathrm{yrs}$, and for one special purpose glass microfibre $6.5 \mathrm{yrs}$. This is quite short compared to the $100 \mathrm{yrs}$ or more lifetime assessed or estimated for natural fibres.

Acid resistance also increases with the silica-aluminium and boron content [30]. In addition, rock- and slag wools are less resistant to acid solutions than glass wool and glass fibres [30, 42]. This latter point is of importance for the interpretation of in vivo experiments. Indeed, concerning $\mathrm{pH}$ in body fluids, two different values must be considered, 6.5-7.5 for extracellular fluids and 4.54.8 for macrophage phagolysosomal fluid [43, 44]. It is impossible to take into account all aspects of $\mathrm{pH}$ variability and the presence of several complexing agents in the intra- and extracellular environment [45] in in vitro tests. Biopersistence of MMVF was assessed after intratracheal injection and inhalation of MMVFs in in vivo animal experiments, taking into account both the clearance mechanisms of the lung and fibre durability. After intratracheal injection of rats, rock wool exhibited comparatively limited solubility as compared to glass fibres after 18 month [46]. RCFs and some special purpose microfibres showed increased biopersistence, at a level similar to that of crocidolite, when compared to the current glass or rock fibres [47].

MUHLE et al. [48] recently reported results indicating that the biopersistence of glass fibres is considerably longer than expected from extrapolation of published data on their in vitro dissolution rates. However, it is difficult to compare the different studies and draw definite conclusions because of the differences in experimental design and in size and composition of the tested fibres [40]. Short-term (1 week) exposure of rats to similar aerosols of the respirable fractions of some commercial MMVFs and crocidolite showed the following gradient for fibre biopersistence: crocidolite > rock wool > slagand glass wools [49]. Results for RCFs with the same experimental model have not yet been reported.

Fibre chemistry is not the only parameter that affects in vivo fibre clearance, which appears to be size selective. Fibre length plays an important role. Usually, for durable fibres like amphiboles, longer fibres are cleared more slowly than shorter ones [50]. The same is observed with RCFs [51]. In contrast, long glass fibres are cleared more rapidly than short ones [52-54]. This phenomenon is attributed to differences between intra- and extracellular $\mathrm{pH}$. As glass fibres show less solubility in slightly acidic solutions than at higher $\mathrm{pH}$, the low $\mathrm{pH}$ encountered in macrophage phagosomes would in some way protect completely phagocytosed short fibres (less than $10 \mu \mathrm{m})$ against dissolution. Incompletely phagocytosed longer fibres appear to be subject to enhanced dissolution (resulting in higher fragmentation) by contact with extracellular fluids of higher $\mathrm{pH}[52,53]$.

Morphological aspects of in vitro and in vivo MMVF alteration, confirming their dissolution, were observed by electron microscopy. In in vitro tests, the surface layer of less durable fibres is transformed into a colloidal gel shell [31, 42, 43], or the formation of surface grapelike clusters [31, 43, 55]. More durable fibres, like RCFs, show minimal changes in their surface morphology, consistent with their greater durability [31]. Signs of morphological alteration of MMVF, in some cases almost total disintegration, have also been observed after residence in animal lungs. In vivo, the formation of surface colloidal gel [56], local pitting [51, 57] and thinning of the end of long fibres [45] have also been described. Even the most durable fibres, such as John Manville 100 (JM100) glass fibre or alumino-silicate RCF, show signs of in vivo surface alteration after residence time as short as 6 months in rat lungs [51,57].

\section{Biometrology in human lung tissues}

Only three studies are available [45, 58, 59], which deal with the quantification and characterization of MMVFs by analytical electron microscopy in lung samples of exposed workers. In the largest of these studies [58], fibre content of lung tissue samples from 131 deceased MMVF (glass-, rock- and slag wool) workers from the large US cohort and from 112 matched referents were analysed. The most notable finding in this paper is the absence of any MMVFs in the lung tissue of most exposed workers. The explanation is either that production workers were essentially exposed to nonrespirable fibres or, more probably, that inhaled fibres did not "survive" in the pulmonary environment. In addition, asbcstos fibres were more commonly observed than MMVF fibres, both in workers and in referents. 
The two other studies deal with workers exposed to RCFs. SEBAstien et al. [45] examined the fibre content in the bronchoalveolar lavage (BAL) of seven healthy workers currently employed in a RCF production plant. $\mathrm{Si}-\mathrm{Al}$ fibres similar to ceramic fibres were recovered in the BAL samples from all workers but one (range 63764 fibres $\geq 5 \mu \mathrm{m} \cdot \mathrm{mL}^{-1}$ BAL). RogGLI [59] examined lung tissue from three ceramic fibre workers, including one with adenocarcinoma of the lung and parietal pleural plaques. In both studies, aluminium silicate fibres consistent with RCF were found. Electron microscopy demonstrated alteration of the chemical composition and the morphology of some of those fibres. The formation of ferruginous bodies on RCF mimicking asbestos bodies has been reported.

Thus, in accordance with the experimental in vivo and in vitro data about MMVF durability, these three studies indicate that MMVFs, cven those reported to be the most durable in in vitro test systems and in animal experiments, may undergo some degree of modification of their chemical composition in human lungs. However, the data available are too restricted to draw general conclusions about the biopersistence of all MMVFs in the human lung. The remark made by SEBASTIEN et al. [45] that "even slight modifications in the chemical composition may tremendously affect biopersistence of the fibers", is of special interest in this respect.

In agreement with MCDONALD et al. [58] it can be stated that the biopersistence of insulation wools in human lung is lower than $11 \mathrm{yrs}$. Biopersistence of RCF in human lungs cannot be assessed from the data of SEBASTIEN et al. [45] and RogGLI [59], but it appears that they are inhaled and deposited in the lung, where they undergo modifications.

Finally, among the large amount of data obtained by the most sophisticated electron microscopy techniques on asbestos fibre burdens in lung tissue and BAL of populations of exposed workers, environmentally exposed subjects and members of the general population, the occurrence of MMVFs was rather infrequently reported [60-63]. This is also an argument in favour of the lower biopersistence of the most commonly used MMVFs and/ or for lower exposure levels and/or that MMVFs are less "respirable" than asbestos fibres.

\section{Industrial and environmental hygiene data}

Fibre levels in the workplace have been measured for only two decades. Because of difficulty in comparing data obtained by different counting techniques, a reference scheme for MMVF fibre counting by phase contrast optical microscopy (PCOM) and scanning electron microscopy (SEM) was made available by the World Health Organization (WHO) in 1985 [35, 36].

Although PCOM cannot be used to count fibres with diameters smaller than $0.25 \mu \mathrm{m}$, nor to investigate the chemical composition of the fibres, it remains useful to count fibres in air samples rapidly and at a low cost. SEM makes it possible to count and determine chemistry by energy-dispersive X-ray analysis (EDXA) of fibres with diameters larger than $0.05 \mu \mathrm{m}$.
Fibre levels in workplace air during production. In production plants, airborne fibre concentrations increase when the mean diameter of the fibre under production decreases [38, 64]. Fibre levels at the workplace have been determined by PCOM, SEM and transmission electron microscopy (TEM). Average respirable fibre concentrations recorded in the production of continuous filament range $0.003-0.5$ fibres $\cdot \mathrm{mL}^{-1}$ [65], in insulation wool $0.01-2.0$ fibres $\cdot \mathrm{mL}^{-1}$, most values being lower than 1.0 fibres $\cdot \mathrm{mL}^{-1}$, and for RCFs and special purpose microfibres $0.05-10$ fibres $\cdot \mathrm{mL}^{-1}$ (exceptional values being around 20 fibres $\cdot \mathrm{mL}^{-1}$ ) [66].

Fibre levels of users of MMVF. Although some high peak values have been detected (table 2), levels are commonly lower than 1 fibre $\mathrm{mL}^{-1}$ [27, 67-69]. Highest levels are reached during blowing of insulation wools $[69,70]$.

There is a potential risk for higher exposure in secondary production processes and in end uses in the absence of environmental control measures and proper training about work practice [31]. It must be noted that in application industries the time spent by workers in contaminated atmospheres is generally only a fraction of the total working time $[69,70]$.

MMVF levels in public buildings and homes. From the limited concentration measurements available on MMVF airborne fibre levels in public buildings and homes it can be inferred that values in the range $10^{-4}-10^{-3}$ fibres $\cdot \mathrm{mL}^{-1}$ are expected [71, 72]. Airborne fibre levels measured during major disturbances of loft MMVF insulation ranged $<0.002-0.3$ fibres $\cdot \mathrm{mL}^{-1}[73]$.

Airborne fibre concentrations in the early technological phase of MMVF production. Accurate estimation of past airborne fibre levels is of great importance for the interpretation of the data from the large scale epidemiological studies. Estimations of past fibre levels were attempted, taking into account "upward" and "downward" factors. The most important factors assumed to lead to an increase of airborne fibre levels were the proportion of fine fibres and the increasing production rates.

The main "downward" factors are believed to be the effective use of dust suppressing agents, use of ventilation, and continuous production processes [29]. A model allowing past exposure at each plant to be derived on

Table 2. - Mean airborne man-made vitreous fibre (MMVF) levels in professional applications

\begin{tabular}{lll}
\hline Application & \multicolumn{1}{c}{$\begin{array}{c}\text { MMVF level } \\
\text { fibres } \cdot \mathrm{mL}^{-1} \text { air }\end{array}$} \\
\hline Attic insulation in existing buildings & $0.31-4.2(0.04-15)$ \\
New building insulation & $0.10-0.57(0.013-1.8)$ \\
Ship insulation & $0.12-0.19(0.009-0.63)$ \\
Technical insulation & $0.05-0.37(0.007-1.6)$ \\
Loft insulation & $0.04-82 \quad(0.002-2.1)$ \\
Acoustic insulation & $0.15-0.60(0.11-1.1)$
\end{tabular}

Values are presented as range, and extreme values in parenthesis. (Adapted from [27]). 
the basis of recent airborne fibre measurements and upward or downward factors was built [74]. In a real scale simulation of the early rock/slag wool production process [75], it was demonstrated that the addition of oil as a dust suppressor during the production results in a reduction of the airborne fibre levels from 3-9 times, according to the situation.

\section{Conclusion}

MMVFs differ from asbestos fibres in several ways: 1) they are more soluble (less durable) and less biopersistent with a gradient glass $>$ rock $>$ ceramic; 2) fibres are coarser with a gradient continuous glass filament $>$ insulation wools $>$ ceramic fibres $>$ special purpose glass fibres.

Within the workplace, some particular features should be emphasized: 1) levels of exposure were 2 or 3 orders of magnitude less than that observed in early phases of the asbestos industry; 2) there was exposure to a lot of contaminants, especially during the early phases of the production process; and 3) many workers engaged in the production or use of MMVFs had a pre-existing or concomitant exposure to asbestos.

\section{Experimental data}

\section{In vitro studies}

Objectives of in vitro testing of MMMF. In vitro testing may provide useful information in two main fields. On the one hand, it allows identification of putative mechanisms of fibre toxicity at the cellular level. On the other hand, it provides useful tools for screening the effect of different fibre parameters (e.g. size, chemistry, durability, etc.) on cellular functions or structures. These tests may help in the selection of fibres which should be assessed in long-term inhalation studies, as these are time-consuming and expensive. The interest of such short-term assays in the demonstration of asbestos fibres genotoxic potency has recently been reviewed [76], and was underlined in the evaluation of the pathogenicity of MMVF $[77,78]$.

In vitro models. We have grouped in vitro fibre toxicity studies into the following categories: studies of cytotoxicity; other studies dealing with inflammatory and/or fibrogenic processes; studies of genotoxicity; and studies of cellular transformation. These studies have been performed on various acellular, bacterial or cellular systems, mainly rodent cells and human cells.

As fibres generally form sediments in the culture device (dishes, flasks, etc.), we preferred to express the dose with a similar unit $\left(\mu \mathrm{g} \cdot \mathrm{m}^{-2}\right)$ when information available in the publication allowed such conversion. This approach enabled a comparative interpretation of results observed in different studies, generally using different treatment protocols. The following symbols were employed for the results: $+=$ positive result when comparing data from the fibre-treated group with controls; $\pm=$ indices of some activity in the fibre-treated group, without clearcut interpretation of the data (for example, lack of statistical comparison with controls or suggestion of a weak (nonsignificant) effect when comparing the fibretreated group with controls); - = no effect in the fibretreated cells when compared with control cells.

Results. Results of the different groups of tests studying different biological end-points are summarized in Appendices III-V.

Cytotoxicity (Appendix III). Many studies have been published in this field, mainly for glass fibres, especially glass microfibres. Indices of cytotoxicity strongly correlated with dimensional features, thin and long fibres exhibiting the highest potency on a per mass basis [7981]. Some authors showed that fibre diameter was a less prominent parameter than fibre length in cytotoxicity [80]. It was stated that glass fibres with length and diameter distributions similar to those of asbestos had a comparable toxicity in vitro [82]. Little information was available on other MMVFs, except RCFs where cytotoxicity was observed when diameter was less than $2 \mu \mathrm{m}$. Difficulties in comparing these intercomparisons of results must be emphasized, mainly due to the lack of detailed information on fibre characteristics (size, chemistry).

Inflammatory and/or fibrogenic processes (Appendix IV). Relatively similar conclusions on the role of fibre dimension was reached from these few studies [83].

Genotoxicity (i.e. deoxyribonucleic acid (DNA) and chromosome damage) and cellular transformation (Appendix $V)$. These studies focused almost exclusively on glass microfibres. Some interesting facts were noted. Firstly, phagocytosis appears to be an essential initial step for the induction of chromosomal damage [84, 85]. Secondly, long fibres exhibited higher potency than short fibres. Finally, the cell type used for the in vitro assay influences the results: positive results have been reported in rodent cells (generally fibroblastic cells) whilst results were negative in human cells for the same amount of fibres [86]. This observation is supportive of a greater capacity for repair of DNA damage in the latter. Alternatively, different capacities of phagocytosis have been suggested as an explanation, since some of the human cells (such as lymphoid cells) had probably no or poor phagocytic capacity $[86,87]$.

Discussion. In vitro tests have shown that MMVFs induce some biological activity in various cellular systems, as indicated by cytotoxicity studies. The critical role of size parameters (length, diameter) has been emphasized by most of the authors, with a length-dependent increase in toxicity [82]. Thinner fibres exhibit the highest toxicity when evaluated on a per mass basis for fibres with similar length distribution.

Some authors have reported a genotoxic and/or transforming activity of some fibres, mainly thin and 
long glass microfibres in rodent cell systems [84-86, 88-94]. Several possible mechanisms involved in this genotoxic effect have been suggested from these studies. Following internalization by the cells, fibres accumulate in the perinuclear region and may, thus, interfere with chromosome movement during mitosis $[84,85]$. Longer fibres are preferentially phagocytosed [85] and, thus, appear as the best candidates for genotoxic activity. Results of other studies suggest the role of the production of hydroxyl radicals by cells treated with MMVF during the first steps of phagocytosis, as the result of the interaction of MMVF with the plasma membrane of target cells [95]. Such factors could be involved in potential genotoxic effects and/or induction of mesothelial tumours [96]. However, MMVFs appear to be substantially less efficient than natural fibres in the generation of $\mathrm{OH}^{\circ}$ in the absence of external chelated iron [97].

In vitro cellular tests do not take into account some important parameters of fibre toxicity in vivo, e.g. lung deposition, clearance and biopersistence. For example, it is likely that fibre solubility at different $\mathrm{pH}$ should be taken into account when evaluating the pathogenic potency of a given fibre. The roles of other mechanisms, such as transfection of DNA due to a potential carrier effect of fibres having DNA-adsorptive capacity or fibreinduced oncogene activation, remain to be evaluated[78].

\section{In vivo studies}

The potential effects due to airborne fibres in humans can only occur after a complex process of inhalation, deposition, epuration, retention and translocation. The potential biological effects of inhaled fibres are highly dependent on the efficiency of defence mechanisms of the respiratory tract between the initial deposition and the ultimate contact of the fibres with the target cell. As different target cells are involved, toxicologists have developed specific models in order to analyse each type of response.

The in vivo toxicity of MMVFs has been evaluated in rodents through several routes of fibre administration: inhalation, intratracheal instillation, intrapleural or intraperitoneal injection. Several recent publications have reviewed all these studies [77, 98-100]. The comparison between these experiments is extremely difficult, because of differences in methods of administration and in types, number and sizes of fibres used.

Several factors should be taken into account when discussing results from in vivo data:

1) All tests other than chronic inhalation can only explore an intrinsic potential effect on the target tissue that is concerned: the bronchial epithelial cell for intratracheal injection; the mesothelial cell for intrapleural or intraperitoneal injection.

2) Whatever the test used, it cannot be interpreted if the following points have not been documented test by test: detailed description of the dimensional and chemical composition of the fibres used; identification of maximum tolerated dose (control for false negative) [101] and dose at which overload effects arise (control for false positive) [102]; adequate positive (usually asbestos) and negative control groups.

Our aim is to summarize the results and to clarify the differences of intracavity and inhalational tests. We will also illustrate how the interpretation of these types may be difficult, depending on very slight modifications of experimental parameters.

Intracavity studies (tables 3 and 4, and Appendix V). In these tests, fibres are deposited directly in the pleural or peritoneal cavity of animals. The tumour development in the animals is observed during their life. Animal experiments using intracavity injections of MMVFs and

Table 3. - Summary of results obtained by intraperitoneal injection

\begin{tabular}{|c|c|c|c|c|c|}
\hline Type of fibre & $\underset{n}{\text { Animals }}$ & $\begin{array}{c}\text { Studies } \\
\mathbf{n}\end{array}$ & $\begin{array}{c}\text { Negative } \\
\text { results } \\
<10 \% \text { tumours } \\
n\end{array}$ & $\begin{array}{c}\text { Intermediate } \\
\text { results } \\
10-15 \% \text { tumours } \\
\text { n }\end{array}$ & $\begin{array}{l}\text { Positive results } \\
>15 \% \text { tumours } \\
n\end{array}$ \\
\hline Glass wool & 0 & 0 & - & - & - \\
\hline Slag wool & 264 & 4 & 4 & 0 & 0 \\
\hline Rock wool & 395 & 9 & 3 & 3 & 3 \\
\hline $\mathrm{RCF}$ & 156 & 4 & 0 & 1 & 3 \\
\hline
\end{tabular}

RCF: refractory ceramic fibre. See Appendix VI [109, 110]. (Original data in references [105-108, 111]).

Table 4. - Summary of results obtained by intrapleural injection

\begin{tabular}{|c|c|c|c|c|c|}
\hline Type of fibre & $\underset{\mathrm{n}}{\text { Animals }}$ & $\begin{array}{c}\text { Studies } \\
\mathrm{n}\end{array}$ & $\begin{array}{c}\text { Negative } \\
\text { results } \\
<10 \% \text { tumours } \\
n\end{array}$ & $\begin{array}{c}\text { Intermediate } \\
\text { results } \\
10-15 \% \text { tumours } \\
\text { n }\end{array}$ & $\begin{array}{c}\text { Positive results } \\
>15 \% \text { tumours } \\
\mathrm{n}\end{array}$ \\
\hline Glass wool & 234 & 4 & 4 & 0 & 0 \\
\hline Slag wool & 120 & 3 & 3 & 0 & 0 \\
\hline Rock wool & 136 & 3 & 3 & 0 & 0 \\
\hline $\mathrm{RCF}$ & 31 & 1 & 0 & 1 & 0 \\
\hline
\end{tabular}

RCF: refractory ceramic fibre. See Appendix VI [109, 110]. (Original data in [103-104, 112]). 
asbestos [103-108] have contributed strong evidence for the importance of fibre size and shape in relation to their carcinogenic potential. They led to what is practically considered as a "law": the probability of pleural tumours is highest with fibres which measure $0.25 \mu \mathrm{m}$ or less in diameter and $8 \mu \mathrm{m}$ or more in length. It must be remembered that incidence of tumours was also increased by fibres with diameter up to $1.5 \mu \mathrm{m}$ and length higher than $4 \mu \mathrm{m}[103]$.

Injection tests also provided clues about the relationship between biopersistence and carcinogenicity: ceramic fibres obviously have the greatest ability to induce pleural or peritoneal tumours after intracavity injection (tables 3 and 4).

The general conclusion of these tests could be summarized as follows: if a fibrous particle is thin enough and long enough, and if its chemical composition allows the fibrous shape to remain for a sufficiently long period, it may induce mesothelioma in animals when injected in sufficient quantities $\left(10^{6}-10^{9}\right.$ fibres).

Injection tests, and particularly intraperitoneal tests, appear more sensitive than inhalational tests. The higher sensitivity of intracavity tests is probably due to the high delivery of fibres deposited on the target in a short period of time. Since they assess the ability of fine fibres to induce mesothelioma when placed in the pleura or in the peritoneum of animals, there are several aspects that limit their relevance when extrapolated to human health.

Injection studies assume that mechanisms of carcinogenesis are similar for mesothelial cells and for epithelial cells. This is far from evident and, thus, these tests contribute little information about the risk of lung cancer and/or lung fibrosis.

In addition, in these studies high doses of fibres (up to $10^{9}$ ) are delivered directly to the target organ, completely bypassing the inhalation, deposition, clearance and lung defence mechanisms. They also bypass the translocation of the inhaled and retained fibres towards the periphery of the lung or to the pleura, and presume that fibres reach the pleura with unaltered physicochemical properties.
As Collier reported in Paris (1994), the injected mass of fibres may be so high that they aggregate into clumps, remaining free in the peritoneum ("overload effect"). The defenders of the injection tests advocate their sensitivity and simplicity. Some estimate that the sensitivity of the inhalational model is too low for the identification of the carcinogenic potential of mineral fibres, notably because of the negativity of some studies on rats following inhalation of crocidolite asbestos fibres [113].

Inhalational studies. In chronic inhalation studies, animals are exposed to airborne fibres during a substantial fraction of their lifespan, and the occurrence of tumours of the lungs and pleura is assessed during their life. This route of exposure is more similar to human exposure, and explores all possible target organs (upper airways, trachea, bronchi, lungs, pleura).

Three types of inhalational studies have been performed with MMVFs: 1) short-term inhalation studies (5 days) designed to assess biopersistence of different fibres; 2) intermediate inhalation studies (several weeks to several months) designed to assess the initial inflammatory response in order to predict a potential fibrogenic effect; and 3) long-term inhalation studies designed to test fibrogenic and carcinogenic effect by a physiological route, with an adequate level of exposure (up to maximum tolerated dose and less than the dose leading to overload effect).

A large number of studies have been published with MMVF. They are summarized in Appendices VII-IX. However, only recent studies have met the criteria defined during the WHO meeting in Copenhagen (1992), which was organized to discuss the technical approaches of different experimental models [114]. Therefore, we will restrict the analysis to the more recent series obtained in Los Alamos [111], and Geneva [100, 115].

A good example of the difficulties observed in such studies is presented in table 5: two large series, studying inhalation of ceramic fibres, have been performed in rats and in hamsters. A slight variation of diameter was responsible for a huge difference in biological effect.

Table 5. - Comparison of two inhalation studies of refractory ceramic fibres

\begin{tabular}{|c|c|c|c|c|}
\hline & \multicolumn{2}{|c|}{ SMrTH et al. [111] } & \multicolumn{2}{|c|}{ BunN et al. (RCC) [115] } \\
\hline & \multicolumn{2}{|c|}{$\begin{array}{l}\text { Dose: } 12 \mathrm{mg} \cdot \mathrm{m}^{-3}-200 \text { fibres} \cdot \mathrm{mL}^{-1} \\
\text { Scanning electron microscopy } \\
\text { Mean D: } 1.8 \mu \mathrm{m} \\
\text { GMD: } 0.9 \mu \mathrm{m} \\
\text { GML: } 25 \mu \mathrm{m} \\
\text { L }>10 \mu \mathrm{m}: 83 \% \\
\text { D }<2 \mu \mathrm{m}: 86 \%\end{array}$} & \multicolumn{2}{|c|}{$\begin{array}{l}\text { Dose: } 30 \mathrm{mg} \cdot \mathrm{m}^{-3}-200 \text { fibres } \cdot \mathrm{mL}^{-} \\
\text {Optical microscopy } \\
\text { Mean D: } 0.98 \mu \mathrm{m} \\
\text { GMD: } 0.82 \mu \mathrm{m} \\
\text { GML: } 15.9 \mu \mathrm{m} \\
\text { L }>10 \mu \mathrm{m}: 60 \% \\
D<2 \mu \mathrm{m}: 80 \%(<15 \mu \mathrm{m})\end{array}$} \\
\hline & Rat & Hamster & Rat & Hamster \\
\hline Total Animals $\mathrm{n}$ & 55 & 70 & 140 & 140 \\
\hline With fibrosis $n$ & 3 & 2 & 4 & 4 \\
\hline With lung tumours $n$ & 0 & 0 & 20 & 0 \\
\hline With mesothelioma n & 0 & 1 & 2 & 60 \\
\hline
\end{tabular}

D: diameter; GMD: geometric mean diameter; GML: geometric mean length; L: length. 
Indeed, the Los Alamos series could be considered as negative in both species, for fibrosis or tumour. The only mesothelioma observed among hamsters was not significant. On the contrary, results from Geneva were considered as significantly positive for lung fibrosis (more than grade 4 in Wagner scale) and mesothelioma in both species and for lung cancer in rats. Interestingly, these very important differences between the two studies was attributed to the low retention of fibres in the Los Alamos study, due to a slightly larger diameter than in the Geneva study.

Even if an overload effect has been discussed (more than several hundred times the usual concentration at the workplace), the comparison with similar experiments with other MMVFs makes an artefact improbable. Moreover, a dose-response relationship was clearly demonstrated, especially for lung fibrosis (table 6).

Other available data from Geneva concern three types of fibres in the "nose only" rat inhalation model: glass wool, rock wool and slag wool. They are summarized in table 6 and in Appendix VII [104, 111, 115-117].

No significant biological effect (fibrosis, tumour) was reported for glass wool and slag wool at any level of exposure from 25 to 225 fibres $\cdot \mathrm{mL}^{-1}$. For rock wool, a minimal lung fibrosis was reported for the two highest exposed groups (150 and 225 fibres $\cdot \mathrm{mL}^{-1}$ ) without significant excess of any kind of tumour. It should be noted that the number of mesothelioma was extremely low in both chrysotile $(1$ case $=1.4 \%)$ and crocidolite $(1$ case $=0.9 \%)$ "positive" control groups.

Several points should be mentioned:

1. The inhalation model in rodents is inappropriate for fibres with actual diameters more than $1 \mu \mathrm{m}$. All published studies using such fibres were negative, which does not imply that the risk cannot exist for humans.

2. For glass wool, when all inhalational data were gathered, a significant lung tumour enhancement was found [77]. This is consistent with the reanalysis of Wagner's data by PETO [118] when expressing results as number of tumours per 100 fibres $\cdot \mathrm{mL}^{-1} \times \mathrm{h}$.
3. For glass microfibres, all inhalation studies were negative. However, due to the various possible chemical compositions of those special purpose microfibres, it cannot be postulated with certainty that all have been adequately tested. This point should be kept in mind, especially because of contradictory results with intracavity tests.

Discussion. Injection tests produced fundamental information regarding the importance of dimensional parameters of fibres in their ability to induce mesothelioma. However, these studies completely bypass the complex process of inhalation, deposition, epuration, retention and translocation.

As far as the complexity of the model required, animal experiments using inhalation of fibres are considered as the reference model in aerosol toxicology. Inhalation is the route of choice for the end-points of fibrosis, lung cancer and mesothelioma.

Recent inhalational studies, meeting well-defined criteria (WHO), have clearly demonstrated the highest positive results ever observed for MMVF with refractory ceramic fibres, as well as for fibrosis, lung tumours or mesothelioma. No significant biological effect (fibrosis, tumour) was reported for glass wool and slag wool. A minimal lung fibrosis was reported for rock wool, without excess of tumour.

The rat seems to be "resistant" to mesothelioma by inhalation, whereas the hamster appears very sensitive to mesothelioma induction, and "resistant" to lung tumour induction.

It has been postulated that differences in the type of tumour could be related to differences in fibre migration, with a greater translocation of refractory ceramic fibres towards the pleura in hamsters compared to rats.

Even if low mesothelioma rates in the rat inhalation model with asbestos do reflect the human experience, it has been suggested that the use of hamster in the inhalation model should be discussed in order to improve the sensitivity for mesothelioma hazard identification.

Table 6. - Summary of Geneva inhalation studies [100]

\begin{tabular}{|c|c|c|c|c|c|c|}
\hline & \multicolumn{6}{|c|}{ Interstitial fibrosis and tumour results } \\
\hline & $3 \mathrm{mo}$ & $6 \mathrm{mo}$ & $12 \mathrm{mo}$ & $18 \mathrm{mo}$ & $24 \mathrm{mo}$ & Tumours \\
\hline Chrysotile $10 \mathrm{mg} \cdot \mathrm{m}^{-3}$ & + & + & + & + & + & $*(a)$ \\
\hline Crocidolite $10 \mathrm{mg} \cdot \mathrm{m}^{-3}$ & + & + & + & + & + & $*(a)$ \\
\hline \multicolumn{7}{|l|}{ Ceramic } \\
\hline 225 fibres $\cdot \mathrm{mL}^{-1}$ & - & + & + & + & + & $*(a)$ \\
\hline 150 fibres $\cdot \mathrm{mL}^{-1}$ & - & - & + & + & + & - \\
\hline 75 fibres $\cdot \mathrm{mL}^{-1}$ & - & - & + & + & + & - \\
\hline 25 fibres $\cdot \mathrm{mL}^{-1}$ & - & - & - & - & - & - \\
\hline \multicolumn{7}{|l|}{ Rock } \\
\hline 225 fibres $\cdot \mathrm{mL}^{-1}$ & - & - & - & + & + & - \\
\hline 150 fibres $\cdot \mathrm{mL}^{-1}$ & - & & & + & + & - \\
\hline 25 fibres $\cdot \mathrm{mL}^{-1}$ & - & - & - & - & - & - \\
\hline Glass** & - & - & - & - & - & - \\
\hline Slag** & - & - & - & - & - & - \\
\hline
\end{tabular}

+: development of Wagner Grade 4 fibrosis; *: significant increase in tumours relative to air controls; (a): including at least one mesothelioma; **: four exposure groups $\left(25,75,150\right.$ and 225 fibres $\left.\cdot \mathrm{mL}^{-1}\right)$. 


\section{Human data}

\section{Nonmalignant respiratory diseases}

Diseases specifically associated with natural mineral fibres. Asbestos exposure is associated with the following diseases: lung fibrosis (asbestosis); pleural thickening; pleural plaques (hyaline or calcified); and pleural effusion. The possible association of occupational exposure to MMVFs with these lesions, which are essentially radiological findings, has therefore to be considered.

Lung fibrosis (pneumoconiosis). In several studies, chest roentgenograms of MMVF-exposed workers were evaluated. No evidence of an association between exposure and lesions was found [119-122]. WEILL and co-workers $[122,123]$ carried out two cross-sectional studies on the same group of workers from glass-, slag- and rock wool production plants. The chest radiographs were coded according to the International Labour Office (ILO) 1980 classification. In the first study, on 941 radiographic images, small irregular opacities were detected in a low percentage of workers, all with low-grade images: $7 \%$ of $0 / 1 ; 3 \%$ of $1 / 0$; and $0.6 \%$ of $1 / 1$ [122]. The prevalence of abnormalities $(>0 / 1)$ increased with age and cigarette smoking, as well as with exposure to fine fibres among current smokers. In the recent follow-up study, the authors no longer found a significant effect of MMVF exposure on the radiographic findings by comparison to a group of local blue collar workers [123]. Interestingly, there was no evidence of radiographic progression between the two studies (1993), a supplementary argument against the existence of a MMVF-induced lung fibrosis.

It must be kept in mind that low profusions of small opacities must not be considered as evidence for pneumoconiosis. In low-grade categories (up to 1/1), cigarette smoking and age have their effects on ILO gradings when emphysema is present $[124,125]$. Computed tomography (CT) scan studies clearly confirm that small opacities do not necessarily correspond to pneumoconiotic lesions [126]. This misleading interpretation appears in a study on 284 MMVF appliance workers, in whom KILBURN et al. [127] found $15 \%$ of workers with evidence of "pneumoconiosis", including 0/1 category. Apart from considering any radiographic abnormality as pneumoconiosis, as KILBURN et al. [127] did, one should be careful when ascribing lesions to MMVF. In the same study, 17 of 43 workers with radiographic abnormalities had previous asbestos exposure [127].

There have been some case reports of lung fibrosis attributed to MMVF exposure, on the basis of necropsy [127, 128], thoracotomy and transbronchial lung biopsy. The mere association of peribronchiolar and interstitial fibrosis with some ferruginous bodies on glass fibres is not sufficient proof of a causal relationship.

Pleural lesions. In the absence of asbestos exposure, there is no evidence of a relationship between glass-, rock- and slag wool exposure and pleural abnormalities. In the first study by WEILL and co-workers [122], the prevalence of pleural thickening was $1.6 \%(2.3 \%$ in the general US population [129]) and that of pleural plaques was $0.2 \%$.

Interestingly, in one series of workers involved in manufacture of refractory ceramic fibres, $3.4 \%$ had pleural changes considered as pleural plaques. The prevalence reached $11.4 \%$ in the group for whom it was more than 20 yrs since their first RCF production job [130].

Nonspecific respiratory diseases. This group of nonmalignant diseases includes chronic obstructive pulmonary disease (COPD), emphysema, chronic bronchitis and asthma. They are evaluated mainly by questionnaire (phlegm, cough) and lung function tests. Several studies have been undertaken to evaluate these possible effects of MMVFs on the respiratory system. These studies were all of cross-sectional character, which could lead to an underestimation of the risk, if diseased workers are more likely to leave the workforce than healthy workers. This phenomenon is not likely in the case of non-seriously disabling diseases, such as a nonclinical reduction in lung function. These studies are difficult to compare to each other, since different parameters have been used. Nevertheless, the results of most studies do not support an increase in nonmalignant respiratory disease due to exposure to glass- and rock wool in the production industry.

Moulin et al. [131] studied 2,024 workers from glassand rock wool plants in France, and found only a correlation between respiratory symptoms, age and smoking. More recent studies [123, 132] have confirmed the absence of any relationship between respiratory symptom/loss of pulmonary function and exposure to MMVF. CHIAZZE et al. [132] demonstrated that only the smoking variable was significantly associated with nonmalignant respiratory disease. The last follow-up of the USA cohort study [34] found no evidence of a relationship between MMVF exposure and deaths from nonmalignant respiratory disease. The 1988 IARC Review concluded that there is no proof of an association between occupational exposure to MMMF and nonmalignant respiratory disease [27].

Some data indicate that there may be an interaction between smoking and fibre exposure in the causation of obstructive airway disease in ceramic production workers. Cumulative exposure to RCF could cause airways obstruction by promoting the effects of cigarette smoke [133].

Diseases associated with other substances present in the workplace. As part of exposure to MMVFs, workers involved in MMVF production have experienced exposure to other agents. Co-exposure to asbestos has been observed and documented. Other agents include formaldehyde, silica, talc, asphalt fumes and resins. Of particular environmental interest is the possible contamination of the workplace by microorganisms, due to the high level of humidity and high temperature. Cases of extrinsic allergic alveolitis have been observed in glass filament workers who were exposed to various microscopic fungi, contaminating the air-conditioning system of the factory [134]. 
Table 7. - Values of the SMRs for lung cancer mortality (compared to local rates)

\begin{tabular}{llcc}
\hline Type of industry & $\begin{array}{c}\text { WHO 1988 } \\
{[27]}\end{array}$ & $\begin{array}{c}\text { Revised USA and } \\
\text { European studies } \\
{[34,136]}\end{array}$ & $\begin{array}{c}\text { USA, Canadian and } \\
\text { European combined } \\
\text { studies [143] }\end{array}$ \\
\hline Glass filament & $\begin{array}{l}\text { 92 USA } \\
\text { 97 Europe }\end{array}$ & 111.9 USA & 108.2 \\
Glass fibres & $\begin{array}{l}\text { 109 USA } \\
\text { 103 Europe }\end{array}$ & $\begin{array}{l}113.5^{*} \text { USA } \\
111.4 \text { Europe }\end{array}$ & $114.9^{*}$ \\
$\begin{array}{l}\text { Mineral wool } \\
\text { (rock slag) }\end{array}$ & 134 USA & $134.2^{*}$ USA & $136.2^{* *}$ \\
\hline
\end{tabular}

SMR: standard mortality rate; WHO: World Health Organization. *: p<0.05, Poisson distribution; **: $\mathrm{p}<0.01$, Poisson distribution.

Discussion. There is actually no evidence of a pneumoconiosis risk in workers exposed in the glass-, rock- or slag wool production plants. This is probably due to the low respirable properties and biopersistence of these fibres compared with asbestos. The possible role of ceramic fibres in the development of pleural plaques should be confirmed. There are no studies on large exposed populations with high resolution CT scan. This technique could bring interesting observations, and may reduce the interobserver variability in ILO readings. There is no clear evidence of a relationship between MMVF and nonspecific respiratory disease observed in association with smoking. In this regard, studies on bronchial hyperreactivity in workers exposed to fine respirable fibres could be interesting. The possibility that chronic exposure to fine MMVFs could induce inflammation or irritation of small airways, and create bronchial hyper-responsiveness should be examined*. Large fibres have also been reported to induce chronic pharyngolaryngitis in workers exposed to high concentrations, and it is well-known that skin irritation is very frequent after MMVF exposure [27].

Exposure to several contaminants in the workplace, such as inorganic dust (asbestos), organic substances, or even microorganisms can be the cause of several respiratory diseases not directly related to MMVF.

\section{Malignant respiratory diseases}

Lung cancer (tables 7-9). Several large populations of MMVF production workers have been the subject of extensive epidemiological studies [34, 135-137]. Apart from other smaller studies [138, 139], these studies have provided the major part of the current knowledge on the existence of a cancer risk in MMVF production workers. In the Canadian study, 2,557 workers from one insulation wool plant were followed between 1955 and 1984 [137]. The study population of the American study consisted of 16,661 workers from 17 plants [34]. This population was followed between 1945 and 1985 . In the

*: Such a study has now been carried out and recently reported by Dr Ann Woolcock at the Symposium on the Health effects of fibrous materials held in Sydney, Australia, 1995: there was no evidence for an increased airway responsiveness to histamine in Australian glass wool and rock wool production workers.
Table 8. - American, European and Canadian studies: lung cancer mortality among those followed up for at least 20 yrs* [142]

\begin{tabular}{|c|c|c|c|}
\hline \multirow[b]{2}{*}{ Any MMVF } & \multirow{2}{*}{$\begin{array}{c}\text { Deaths } \\
507\end{array}$} & \multicolumn{2}{|c|}{ SMR 95\% CI } \\
\hline & & 117.1 & $(107-128)$ \\
\hline Mineral fibres & 92 & 136.2 & $(109.9-167.2)^{* *}$ \\
\hline Slag + rock & 81 & 148.9 & $(116-182)$ \\
\hline Rock only & 11 & 90.9 & $(45-153)$ \\
\hline Glass fibres only & 415 & 113.6 & $(102-125)$ \\
\hline $\begin{array}{l}\text { Special purpose } \\
\text { ( } \pm \text { other glass) }\end{array}$ & 17 & 106.9 & $(62-164)$ \\
\hline Wool ( \pm filament) & 321 & 115.4 & $(103-128)$ \\
\hline Filaments only & 77 & 108.3 & $(84-133)$ \\
\hline
\end{tabular}

SMR: standard mortality rate; $95 \% \mathrm{CI}$ : 95\% confidence interval; MMVF: man-made vitreous fibre. *: a latency of 15 yrs for the Canadian glass filament study; **: calculated according to the method proposed by BRESLOW and DAY [144] (1987).

Table 9. - Summary of the evidence in favour of and against a causal role of MMVF* and lung cancer

Evidence in favour

1. Similarities of SMRs for lung cancer in the main cohort studies

2. Elevated SMRs are found for lung cancer only

3. Parallel between the lung cancer SMRs and the airborne concentration of the fibres

Evidence against

1. No increase of lung cancer risk with increase of exposure duration

2. The increase in lung cancer occurred mostly in workers producing slag wool in the early production phase, which contained traces of arsenic, a well-established human lung carcinogen

3. Documented exposures to other agents in the workplace known to be capable of inducing lung cancer, including asbestos and polycyclic aromatic hydrocarbons (PAH)

4. Lack of risk for lung cancer in case-control studies adjusted for smoking

MMVF: man-made vitreous fibre; SMR: standard mortality rate. *: slag-, glass- and rock wool. 
European study conducted by the IARC, 21,967 workers from 14 plants were followed between 1953 and $1981[135,136]$. The results of these studies have been pooled to derive overall estimates of the cancer risks in MMVF production workers in several instances [140143].

The pooled estimates of the three studies, for workers after a follow-up of $20 \mathrm{yrs}$ or more are given in tables 7 and 8. According to the most recent review by WeILL and co-workers [143] (table 7), the standard mortality rates (SMRs) for glass wool and all mineral wool combined (rock/slag) are significantly elevated $(\mathrm{p}<0.01$, Poisson distribution) as compared with regional rates. No other type of cancer is observed in excess which makes the elevation of the SMRs more consistent, and suggests the role of one (or more) inhaled carcinogenic agents.

The independent American and European cohorts show similar results, and in particular very close SMRs in the different types of exposure: respectively, 113.5 and 111.4 for glass wool and 134.2 and 139.9 for mineral (rock/slag) wool. A very recent follow-up by BofFeTTA et al. [145] has shown following values for the SMRs: 132 for the whole cohort $(\mathrm{p}<0.05) ; 137$ for rock/slag wool $(\mathrm{p}<0.05)$, and 127 for the glass wool $(\mathrm{p}<0.05)$. The highest SMRs are found in the subcohorts of workers exposed in the early technological phase, where SMRs as high as 257 have been reported [135]. The lung cancer mortality increases with time since first exposure to a maximum after $30 \mathrm{yrs}$ or more [140]. In addition, the SMRs for lung cancer in slag wool, glass wool and rock wool workers seem to run parallel to the average fibre exposure expressed as fibres. $\mathrm{mL}^{-1}$ [34].

All these facts seem to support a possible role of exposure to MMVFs in lung cancer risk. Nevertheless, several subcohort analyses within these populations and additional data have provided evidence that raises some doubt about the direct relationship between MMVF exposure and lung cancer.

Firstly, an analysis by duration of employment, as a surrogate for dose, indicated that the risk of lung cancer mortality did not increase with a longer duration of exposure. On the contrary, the excess of lung cancer appeared to be limited to those workers with a relatively short duration of exposure. In the European study, for instance, the SMR for lung cancer in the workers employed for less than 5 yrs was 152 . In the subgroup of workers employed for 5 yrs or more, no increased risk for lung cancer mortality was observed [135]. Similar results were obtained in the American [146] and Canadian studies [137]. It must, however, be stated that short duration does not necessarily mean a low cumulated exposure. Moreover, this means that the exposure to other agents (asbestos, arsenic) was also short, even if these are incriminated.

Secondly, it was noted that the highest increased risk for lung cancer mortality occurred in the workers exposed to slag wool. Some types of slag are known to contain significant amounts of arsenic, a human carcinogen, although it has never been proven to be the causal agent responsible for the excess lung cancer mortality in slag wool workers. Since rock wool plants had produced slag wool at one time or an other, the excess lung cancer mortality in the mineral (rock + slag) wool group could be related to the production of slag wool. That the actual Research and Consulting Company (RCC) inhalational studies found no tumours in animals could, in part, be explained by the fact that actual slag fibres have different compositions to the slag wool used several decades ago.

Thirdly, in several plants included in the studies, evidence has surfaced of concomitant exposure to asbestos and bituminous fumes [33]. For one plant in the American study, there is documentation that confirms the extensive use of asbestos. These observations were further substantiated by the later finding of amosite fibres in the lung tissue of deceased MMVF workers [58]. However, the use of asbestos is an unlikely candidate to account for all of the excess of lung cancer, particularly in a population in whom no apparent excess in mesothelioma cases has been detected. As reported by ENTERLINE [147], SMR for respiratory cancer was 258 in two slag wool plants in which asbestos was never used.

In order to acquire a better understanding of the working conditions in the past, an old glass wool plant was reopened [32]. In this experiment, one of the oldest production lines was taken out of the normal production and was modified according to the production process of around 1940. From these experiments, it was learned that concomitant exposure to PAH occurred on a regular basis, as had also been reported by CHERRIE et al. [38]. The description of the working conditions in the past, as presented by FALLENTIN and KAMSTRUP [32], makes it quite clear that the health status of workers of this industry must be evaluated within the total complex and heavily polluted working environment of the past.

A fourth issue that has given grounds for considerable doubt is the possible confounding effect of cigarette smoking. Wong et al. [148] carried out a nested case-control study within the American cohort of slag wool workers to further investigate this matter. The 55 cases of lung cancer were matched to a comparable group of 98 controls, all members of the cohort, and additional data were collected on smoking habits. A strong relationship was observed between cigarette smoking and lung cancer. After adjustment for smoking, the originally observed relationship between fibre exposure and lung cancer risk had disappeared. These findings run parallel to the results from another case-control study carried out in Norway [149]. However, this was a hospital-based case-control study and not a nested case-control study within a cohort of occupationally exposed workers. The results reported by WONG [148] (1991) were subsequently confirmed in a similar study carried out by CHIAZZE and co-workers [150] (1993).

Another argument that weakens possible increased lung cancer risk after MMVF exposure concerns studies in which there was a smaller increase in lung cancer mortality if comparisons were made with local rather than national mortality rates. In the study of 16,661 American MMVF production workers, the total SMR for respiratory cancer decreased from 121.5 to 112.5 after comparing the cohort to local death rates.

There are insufficient epidemiological data available for workers exposed to ceramic fibres, because of the 
smaller size of the workforce and of the more recent technology.

Mesothelioma. Inherent to their study design, the cohort studies of glass-, slag- and rock wool production workers also provide data on the incidence of mesothelioma. In all three retrospective cohort studies, the mortality rate from mesothelioma is well within the expected range. In the American study, for example, four deaths were recorded as mesothelioma [34]. Two of these were eventually coded as actual mesothelioma, compared to an expected number of 1.45. Recently, the results of a case-control study of 268 mesothelioma cases and 221 controls was reported [151]. For all study subjects, an evaluation was made of their past exposure to asbestos and to other mineral fibres; more than $80 \%$ of the subjects who had been exposed to MMVFs had also been exposed to asbestos. At first, there appeared to be a relationship between glass- and rock wool exposure and mesothelioma, which almost completely disappeared after adjustment for asbestos exposure. However, because of the strong association between asbestos and mesothelioma, it seems most likely that this relationship is caused by residual confounding rather than by a true effect. The general consensus on this issue is that no increase in risk of mesothelioma has been demonstrated in the glass-, slag- and rock wool industry. This is consistent with the absence of increased prevalence of pleural plaques or pleural fibrosis in these industries. Nevertheless, according to the very long latency of this disease, and also due to the difficulty of its diagnosis, this needs further survey. There are no data for workers exposed to ceramic fibres, essentially because of the smaller size of this group, and also because of the need for a long follow-up (more recent technology).

Discussion. An excess of mortality from lung cancer has been demonstrated in the MMVF production industry. The risk concerns mainly the workers exposed in the slag wool industry during the early technological phase. Nevertheless, the epidemiological cohort studies are limited by the inability to control confounding variables, such as smoking, concomitant exposure to other carcinogens, and lack of quantitative data (e.g. fibre levels). Since they have no experimental character, the occurrence of disease can be the result of variations of several causal factors. The data available do not make it possible to conclude whether the risk of lung cancer is due to the MMVFs themselves or to other carcinogens present at the workplace (asbestos, arsenic, PAH) or not (smoking).

Recently (Berlin, 1993), R. Saracci estimated that the recent reanalyses of the cohorts do not modify the data available in 1988. This means that there is limited evidence of carcinogenicity for mineral wool and inadequate evidence for glass wool. The IARC definitions are as follows: as far as human evidence from epidemiological studies is concerned, limited evidence of carcinogenicity means "A positive association has been observed between exposure to the agent and cancer, for which a causal interpretation is considered by the Working Group to be credible, but chance, bias or confounding could not be ruled out with reasonable confidence", and inadequate evidence of carcinogenicity means "The available studies are of insufficient quality, consistency or statistical power to permit a conclusion regarding the presence or absence of a causal association".

No increase in mesothelioma risk has been demonstrated in the cohorts of workers exposed to glass-, slagor rock wool.

It must be kept in mind that epidemiological studies also have limitations in discriminating between the lack of any risk and the possibility of a small risk. This is particularly true if the final conclusion relies heavily on statistical significance testing. That there persists a doubt for lung cancer and not for mesothelioma seems sound for a clinician [152]. Indeed, one could ask if the factors that determine the fibre's respiratory characteristics and durability, very important for lung fibrosis and mesothelioma, are as relevant for the development of cancer of proximal airways, which are more easily reached by aerocontaminants. A final comment is that there are no available epidemiological data on the glass wool subcategory of superfine fibres $(<1 \mu \mathrm{m}$ diameter $)$ and on ceramic refractory fibres.

In conclusion, the assessment of the respiratory health effects of MMVF is a very complex issue. Several aspects of the problem contribute to this complexity:

1. There are numerous types of synthetic mineral fibres, with different physicochemical and morphological characteristics, which are parameters influencing their potential toxicity. The term MMVF includes very large nonrespirable glass filaments as well as very fine biopersistent ceramic fibres.

2. It is conceptually difficult to extrapolate the results from cellular and animal studies to humans. The relevance for man of the injection experiments which bypass respirability, clearance and translocation mechanisms has been discussed. Inhalational studies are more realistic, but show important differences between animal species regarding their sensibility to tumour induction by fibres. The former model is probably too sensitive, the latter may be not sensitive enough.

The critical role of size parameters has been demonstrated in cellular and injection studies, when intact fibres are in direct contact with the target cells. Fibre biopersistence and probably translocation are important factors, as suggested by the induction of mesothelioma after inhalation of refractory ceramic fibres.

These experimental observations bring consistent evidence that some types of MMVF are bioactive under certain conditions. This is sufficient, anyway, to consider their potential toxicity in human epidemiological and clinical studies.

3. There is no firm evidence that exposure to glass-, rock- and slag wool is associated with mesothelioma, lung fibrosis, pleural disease or nonspecific respiratory diseases in humans.

4. An elevated SMR for lung cancer has been demonstrated for workers employed in the early technological phase of mineral (slag-rock) wool production. During 
that period, several carcinogenic agents (arsenic, asbestos, PAH) were present in the workplace, and quantitative data about smoking and fibre levels are lacking. It is not possible to definitively prove or rule out the role of MMVFs in the development of lung cancer during that period. It does not appear contradictory for clinicians that MMVFs would be associated with bronchial carcinoma and not with pleural mesothelioma. Indeed, the factors that determine fibre respiratory characteristics, durability and translocation are possibly less relevant for the bronchial mucosa of proximal airways than for the pleura.

5. There are insufficient data available for ceramic fibre production workers. The reasons for this are a relatively recent industrial production (regarding the long latency of mesothelioma) and the smaller size of the workforce. The possible occurrence of pleural plaques in this kind of exposure is an important issue, which needs confirmation.

6. In evaluating the possible health effects of MMVF, it is also important to keep in mind the exposure concentration that can be observed in present working conditions. The industrial hygiene data available indicate very low levels of fibre exposure in the actual production plants. Even if these levels concerned asbestos fibres, they would probably implicate a very low, possibly undetectable health risk. MMVF levels in buildings are extremely low, so that this cannot be considered as an environmental risk.

7. Clinicians should be aware that there are very few data that report the exposure conditions of end-users (applicators, insulators); personal data suggest a need for caution. During an experimental spraying of an asbestos substitute labelled as "mineral wool", analysis of air samples revealed a dense aerosol of ceramic fibres with Stanton dimensions. This illustrates the difficulty in the assessment of exposure risk and the need for detailed occupational hygiene data. It is even more true that clinicians will not have access to objective indicators of exposure and/or retention in biological samples, as they had for asbestos (BAL, lung tissue). Indeed, it appears that the presence of MMVFs or ferruginous bodies on MMVFs in lung tissue is not correlated with exposure, especially when exposure has ceased for several years.

\section{Appendix}

Appendix I: MMVF - chemical composition*

\begin{tabular}{|c|c|c|c|c|c|c|}
\hline \multicolumn{6}{|c|}{ Composition \% } & \\
\hline & & \multicolumn{3}{|c|}{ Insulation wool } & \multirow{2}{*}{$\begin{array}{c}\text { Refractory } \\
\text { ceramic } \\
\text { fibres }\end{array}$} & \multirow{2}{*}{$\begin{array}{c}\text { Special } \\
\text { purpose } \\
\text { fibres }\end{array}$} \\
\hline & & Glass wool & Rock wool & Slag wool & & \\
\hline $\mathrm{SiO}_{2}$ & $53-65$ & $57-70$ & $40-57$ & $38-52$ & $37-57$ & $54-69$ \\
\hline $\begin{array}{l}\text { Alkaline oxides } \\
\left(\mathrm{Na}_{2} \mathrm{O}, \mathrm{K}_{2} \mathrm{O}\right)\end{array}$ & $62-15$ & $12-18$ & $0.5-5$ & $0.5-3$ & $<1$ & $11-23$ \\
\hline $\begin{array}{l}\text { Earth alkalis } \\
\left(\mathrm{CaO}_{3}, \mathrm{MgO}\right)\end{array}$ & $4-25$ & $8-15$ & $18-40$ & $30-45$ & $<1$ & $3-24$ \\
\hline Iron oxides & $0.1<1$ & $<0.5$ & $3-15$ & $0-5$ & $<1$ & $<0.4$ \\
\hline $\mathrm{B}_{2} \mathrm{O}_{2}$ & $0-9$ & $0-10$ & Trace & Trace & $<1$ & $3.3-11$ \\
\hline $\mathrm{Al}_{2} \mathrm{O}_{3}$ & $0.7-25$ & $0-5$ & $0-20$ & $5-16$ & $30-60$ & $0-15$ \\
\hline $\mathrm{TiO}_{2}$ & $0-3$ & Trace & $0.5-4$ & $<1$ & $<1$ & $0-8$ \\
\hline $\mathrm{ZrO}_{2}$ & $0-15$ & 0 & 0 & 0 & $0-20$ & $0-4$ \\
\hline
\end{tabular}

Appendix II: historical facts concerning the production of MMVF

\begin{tabular}{|c|c|c|c|}
\hline Data & Historical facts & $\begin{array}{l}\text { Evolution of mean diameter } \\
\text { in insulation wools }\end{array}$ & Technological phase \\
\hline 1885 & First industrial production of slag wool (GB) & & \\
\hline 1897 & First industrial production of rock wool (US) & & Early \\
\hline \multirow[t]{3}{*}{$1930 \mathrm{~s}$} & Industrial production of glass wool (US) & $30 \mu \mathrm{m}$ & \\
\hline & Experimental production of continuous filaments & & \\
\hline & Introduction of dust suppressing agents & & \\
\hline \multirow[t]{2}{*}{$1940 \mathrm{~s}$} & Production of fine fibres $(\phi \approx 1 \mu \mathrm{m})$ & & \\
\hline & Experimental production of RCF & & (Intermediate) \\
\hline $1950 \mathrm{~s}$ & Production of ultra-fine glass fibres $(\phi<1 \mu \mathrm{m})$ & & \\
\hline $1960 \mathrm{~s}$ & Industrial production of continuous filaments & & \\
\hline \multirow[t]{2}{*}{1970 s } & Industrial production of $\mathrm{RCF}$ & $4-6 \mu \mathrm{m}$ & \\
\hline & Measurement of airborne fibre concentrations in production plants & & Late \\
\hline
\end{tabular}

MMVF: man-made vitreous fibre; RCF: refractory ceramic fibre. 
Appendix III: studies of cytotoxicity with MMVFs

\begin{tabular}{|c|c|c|c|c|c|c|}
\hline \multirow[t]{2}{*}{ Fibre type } & \multirow[t]{2}{*}{ Cell type } & \multirow[t]{2}{*}{ Species } & \multicolumn{2}{|c|}{ Maximal dose } & \multirow[t]{2}{*}{ Result (c) } & \multirow[t]{2}{*}{ [Ref]. } \\
\hline & & & (a) & $\mu \mathrm{g} \cdot \mathrm{cm}^{-2}(\mathrm{~b})$ & & \\
\hline $\begin{array}{l}\text { GF } \\
\text { Glass powder }\end{array}$ & Lung and peritoneal macrophages & Guinea-pig & $300 \mu \mathrm{g}$ & ND & $\begin{array}{l}+ \\
+\end{array}$ & {$[153]$} \\
\hline GF & Lung fibroblasts & Rabbit & $?$ & 18 & $\begin{array}{l}+ \\
\pm\end{array}$ & {$[154]$} \\
\hline \multirow[t]{3}{*}{$\mathrm{JM} 100 \mathrm{~T}$} & Peritoneal macrophages & Mouse & $160 \mu \mathrm{g} \cdot \mathrm{mL}^{-1}$ & 33 & $+(d)$ & {$[88]$} \\
\hline & A549 type II alveolar cells & Human & $300 \mu \mathrm{g} \cdot \mathrm{mL}^{-1}$ & ND & + & \\
\hline & V79-4 & Hamster & $200 \mu \mathrm{g} \cdot \mathrm{mL}^{-1}$ & ND & + & \\
\hline \multirow[t]{3}{*}{ JM100 R } & Peritoneal macrophages & Mouse & $160 \mu \mathrm{g} \cdot \mathrm{mL}^{-1}$ & 33 & + & \\
\hline & A549 type II alveolar cells & Human & $160 \mu \mathrm{g} \cdot \mathrm{mL}^{-1}$ & ND & + & \\
\hline & $V 79-4$ & Hamster & $200 \mu \mathrm{g} \cdot \mathrm{mL}^{-1}$ & ND & + & \\
\hline \multirow[t]{3}{*}{ JM110 T } & Peritoneal macrophages & Mouse & $160 \mu \mathrm{g} \cdot \mathrm{mL}^{-1}$ & 33 & - & \\
\hline & A549 type II alveolar cells & Human & $300 \mu \mathrm{g} \cdot \mathrm{mL}^{-1}$ & ND & + & \\
\hline & V79-4 & Hamster & $200 \mu \mathrm{g} \cdot \mathrm{mL}^{-1}$ & ND & \pm & \\
\hline \multirow{3}{*}{ JM110 R } & Peritoneal macrophages & Mouse & $160 \mu \mathrm{g} \cdot \mathrm{mL}^{-1}$ & 33 & + & \\
\hline & A549 type II alveolar cells & Human & $100 \mu \mathrm{g} \cdot \mathrm{mL}^{-1}$ & ND & + & \\
\hline & V79-4 & Hamster & $200 \mu \mathrm{g} \cdot \mathrm{mL}^{-1}$ & ND & + & \\
\hline JM100 & Primary fibroblasts & Human & $100 \mu \mathrm{g} \cdot \mathrm{mL}^{-1}$ & 50 & + & [86] \\
\hline JM110 & & & & & - & \\
\hline JM100 & Peritoneal macrophages & Mouse & $160 \mu \mathrm{g} \cdot \mathrm{mL}^{-1}$ & 33 & + & [155] \\
\hline JM110 & & & & & - & \\
\hline $\begin{array}{l}\text { JM110 R } \\
\text { RW }\end{array}$ & & & & & + & \\
\hline $\begin{array}{l}\text { RW } \\
\text { SW }\end{array}$ & & & & & & \\
\hline $\begin{array}{l}\text { SW } \\
\text { GW }\end{array}$ & & & & & $\begin{array}{l} \pm \\
+\end{array}$ & \\
\hline Borosilicate glass & P388D1 & & $100 \mu \mathrm{g} \cdot \mathrm{mL}^{-1}$ & ND & + & {$[156]$} \\
\hline Fine GF & Ascites tumour cells & Rat & $256 \mu \mathrm{g} \cdot \mathrm{mL}^{-1}(\mathrm{e})$ & ND & + & {$[157]$} \\
\hline Ultrafine GF & & & 21.6 & & - & \\
\hline JM100 & & & 216 & & + & \\
\hline JM104 & & & 292 & & + & \\
\hline GF & Primary bronchial cells & Human & $100 \mu \mathrm{g} \cdot \mathrm{mL}^{-1}$ & ND & + & {$[158]$} \\
\hline JM100 & Lung macrophages & Dog & $?$ & ND & + & {$[83]$} \\
\hline AA-10 & & & & & + & \\
\hline $\begin{array}{l}\text { GF } \\
\text { GF } 4106-23-7\end{array}$ & Lung macrophages & Guinea-pig & 100 ug. $10^{-6}$ cells & $\mathrm{ND}$ & $\bar{t}$ & {$\left[\begin{array}{ll}82 & 159\end{array}\right]$} \\
\hline GF $4106-24-2$ & 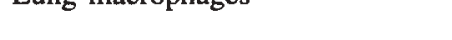 & Gumed-pig & $\left(30 \mu \mathrm{g} \cdot \mathrm{mL}^{-1}\right)$ & ND & $\begin{array}{l}+ \\
+\end{array}$ & {$[82,159]$} \\
\hline GF $4106-4-3$ & & & & & $-/ \pm$ & \\
\hline GF 4106-19-2 & & & & & + & \\
\hline GF 4106-6-1 & & & & & - & \\
\hline GF 4106-19-1a & & & & & $-/ \pm$ & \\
\hline JM100 unmilled & Tracheal epithelial cell line $2 \mathrm{C} 5$ & Rat & & 8 & + & {$[160]$} \\
\hline JM100 milled & & & & & - & \\
\hline JM100 unmilled & SHE cells & Hamster & & 10 & + & [90] \\
\hline $\begin{array}{l}\text { JM100 milled } \\
\text { JM110 }\end{array}$ & & & & & $\begin{array}{l} \pm \\
+\end{array}$ & \\
\hline $\begin{array}{l}\text { JM110 } \\
\text { JM100 unmilled }\end{array}$ & SHE & Hamster & & 1 & $\begin{array}{l}+ \\
+\end{array}$ & [85] \\
\hline JM100 milled & & & & & \pm & \\
\hline JM100 & SHE & Hamster & & 80 & + & [91] \\
\hline JM110 & & & & & + & \\
\hline Coarse GW & $\begin{array}{l}\text { Immortalized mesothelial } \\
\text { cells MeT-5A }\end{array}$ & Hamster & & 100 & + & {$[161]$} \\
\hline Coarse RW & & & & & + & \\
\hline Thin RW & & & & & + & \\
\hline Thin GW & & & & & + & \\
\hline \multirow[t]{3}{*}{ Ceramic fibre } & P388D1 & & $50 \mu \mathrm{g} \cdot \mathrm{mL}^{-1}$ & ND & - & {$[80]$} \\
\hline & V79-4 & Hamster & & & - & \\
\hline & A549 cells & Human & & & - & \\
\hline \multirow[t]{2}{*}{ Ceramic fibre } & V79-4 & Hamster & $100 \mu \mathrm{g} \cdot \mathrm{mL}^{-1}$ & 25 & - & [153] \\
\hline & A549 cells & Human & $50 \mu \mathrm{g} \cdot \mathrm{mL}^{-1}$ & 10 & + & \\
\hline Ceramic fibre & P388D1 & & $50 \mu \mathrm{g} \cdot \mathrm{mL}^{-1}$ & ND & - & {$[162]$} \\
\hline RCF1 & Ovary cells & Hamster & & 30 & + & [94] \\
\hline RCF2 & & & & & + & \\
\hline RCF3 & & & & & + & \\
\hline RCF4 & & & & & + & \\
\hline
\end{tabular}

GF: glass fibres; GW: glass wool; JM: John Manville glass microfibres; RW: rock wool; SW: slag wool; JM100 T: total fibres: JM100 R: respirable fibres; SHE: Syrian hamster embryo; RCF: refractory ceramic fibre; MMVFs: man-made vitreous fibres; ND: not determined. (a): dose mentioned in the original publication; (b): dose indicated by the authors or calculated from data available in the original publication, when not expressed in $\mu \mathrm{g} \cdot \mathrm{cm}^{-2} ;(\mathrm{c})$ : following symbols were employed for the results; $+=$ positive result was observed when comparing data from the fibretreated group with controls; $\pm=$ there were indices of some activity in the fibre-treated group, without clear-cut interpretation of the data (for example, lack of statistical comparison with controls or suggestion of a weak (nonsignificant) effect when comparing the fibre-treated group with controls; - = there was no effect in the fibre-treated cells when compared with control cells: (d): JM100 fibres exhibited a higher effect than JM110 on a per weight basis, while an inverse pattern was observed on a per number basis; (e): dose extrapolated from data of the original manuscript. 
Appendix IV: other studies dealing with inflammatory and/or fibrogenic processes induced by MMVFs

\begin{tabular}{|c|c|c|c|c|c|c|}
\hline \multirow[t]{2}{*}{ Fibre type } & \multirow[t]{2}{*}{ Cell type } & \multirow[t]{2}{*}{ Species } & \multicolumn{2}{|c|}{ Maximal dose } & \multirow[t]{2}{*}{ Result (c) } & \multirow[t]{2}{*}{ [Ref]. } \\
\hline & & & (a) & $\mu \mathrm{g} \cdot \mathrm{cm}^{-2}(\mathrm{~b})$ & & \\
\hline JM100 & Subcutaneous fibroblasts & Rat & Not stated & ND & + & {$[163]$} \\
\hline JM110 & & & & & + & \\
\hline JM100 & Lung macrophages & Rat & $100 \mu \mathrm{g} \cdot \mathrm{mL}^{-1}$ & ND & + & [79] \\
\hline JM100 milled & & & & & \pm & \\
\hline JM100 & Tracheobronchial epithelial cells & Hamster & & 2.6 & + & {$[164]$} \\
\hline Glass particles & & & & & - & \\
\hline \multirow[t]{2}{*}{$\mathrm{JM} 100$} & Alveolar macrophages & Rat & & 5 & + & [95] \\
\hline & Alveolar macrophages & Hamster & & & + & \\
\hline \multirow[t]{2}{*}{ Glass beads } & Alveolar macrophages & Rat & & & \pm & \\
\hline & Alveolar macrophages & Hamster & & & - & \\
\hline RW I & PMN leucocytes & Human & $1000 \mu \mathrm{g} \cdot \mathrm{mL}^{-1}$ & ND & + & [97] \\
\hline RW II & & & & & + & \\
\hline GW & & & & & + & \\
\hline $\mathbf{R C F}$ & & & & & \pm & \\
\hline JM100 & Acellular system & & $1000 \mu \mathrm{g} \cdot \mathrm{mL}^{-1}$ & NA & + & [96] \\
\hline GW & & & & & + & \\
\hline GF & Calf thymus DNA & & $5000 \mu \mathrm{g} \cdot \mathrm{mL}^{-1}$ & NA & + & [165] \\
\hline
\end{tabular}

PMN: polymorphonuclear (leucocytes); DNA: deoxyribonucleic acid; NA: not applicable. For further abbreviations and explanation of (a)-(c) see legend to Appendix III.

Appendix V: studies of genotoxicity and cellular transformation with MMVFs

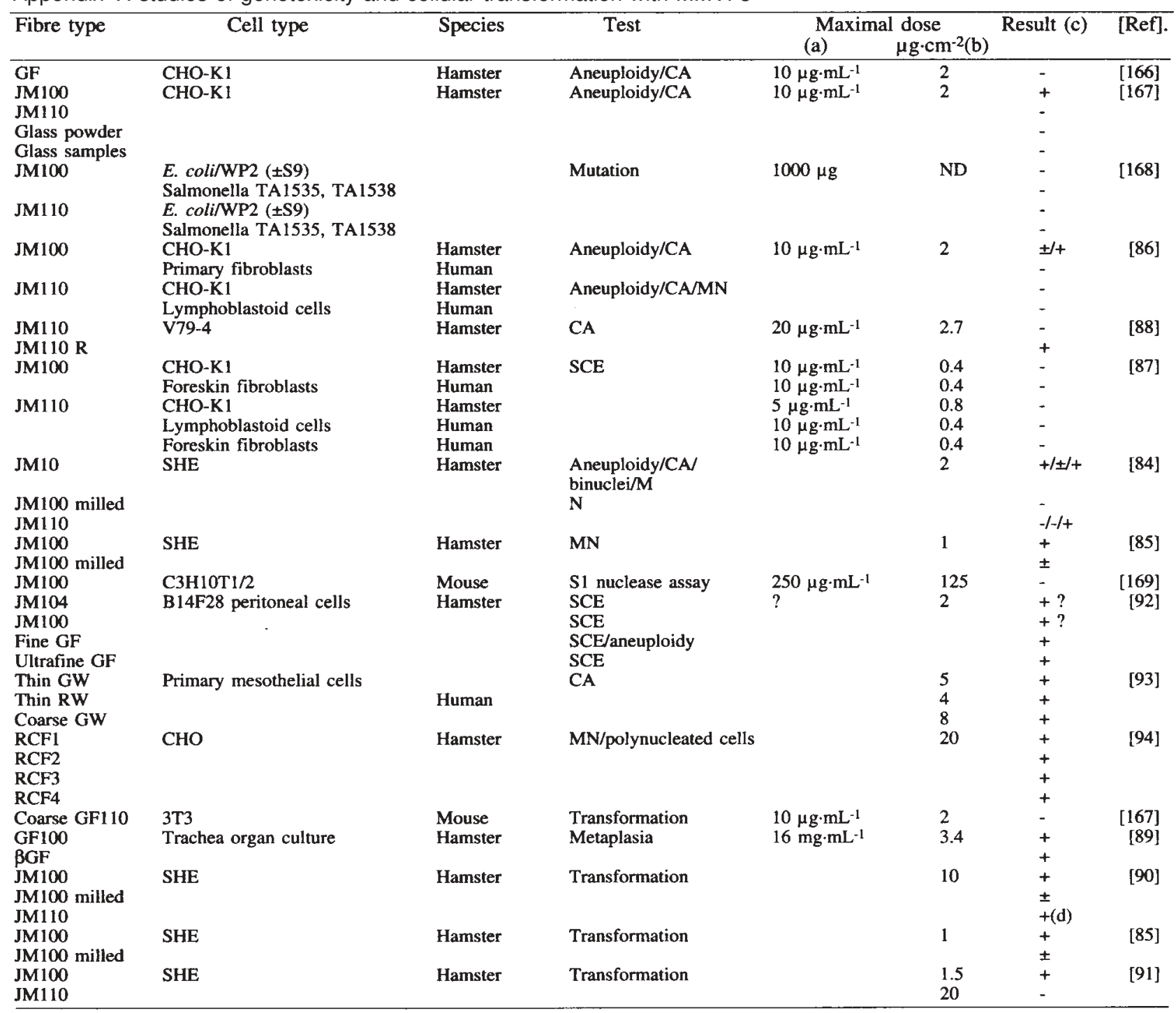

CA: chromosomal aberration; MN: micronucleus; SCE: sister chromatid exchange. For further abbreviations and explanations of (a)-(d) see legend to Appendix III. 
Appendix VI: summary of experimental studies - Lifetime Carcinogenicity [109]

\begin{tabular}{|c|c|c|c|c|c|}
\hline Species & $\begin{array}{c}\text { Route of } \\
\text { administration }\end{array}$ & $\underset{n}{\text { Animals }}$ & $\begin{array}{l}\text { Tumours: } \\
\text { lung/cavity }\end{array}$ & $\begin{array}{l}\text { Experimental } \\
\text { groups } \\
\mathrm{n}\end{array}$ & $\begin{array}{l}\text { Observations and } \\
\text { remarks }\end{array}$ \\
\hline \multicolumn{6}{|c|}{ Pyrex glass fibres } \\
\hline Rats & Intrapleural & 25 & 1 (sarcoma) & 1 & Negative \\
\hline \multicolumn{6}{|c|}{ Continuous filament } \\
\hline Rats & Intrapleural & 92 & 3 (sarcoma) & 2 & Both negative \\
\hline Rats & Intraperitoneal & 217 & 14 (unspecified) & 5 & 4 negative, 1 intermediate \\
\hline \multicolumn{6}{|c|}{ Glass insulation wool } \\
\hline Rats & Intrapleural & 234 & $\begin{array}{l}2 \text { (sarcoma, } \\
\text { mesothelioma) }\end{array}$ & 4 & All negative \\
\hline \multicolumn{6}{|c|}{ Glass - type unknown } \\
\hline Rats & Intrapleural & 120 & 3 (sarcoma) & 4 & All negative \\
\hline \multicolumn{6}{|c|}{ Rock insulation wool (basalt or diabase) } \\
\hline Rats & Intrapleural & 136 & 6 (mesothelioma) & 3 & $\begin{array}{l}\text { All experiments within } \\
\text { negative range }\end{array}$ \\
\hline Rats & Intraperitoneal & 40 & 3 (mesothelioma) & 1 & Within negative range \\
\hline \multicolumn{6}{|c|}{ Experimental rock wool (basalt or diabase) } \\
\hline Rats & Intrapleural & 161 & 81 (unspecified) & 3 & 1 intermediate, 2 positive \\
\hline \multicolumn{6}{|c|}{ Rock wool of unknown composition } \\
\hline Rats & Intraperitoneal & 194 & 28 (unspecified) & 4 & $\begin{array}{l}2 \text { negative, } 2 \text { intermediate, } \\
1 \text { positive }\end{array}$ \\
\hline \multicolumn{6}{|c|}{ Slag insulation wool } \\
\hline Rats & Intrapleural & 121 & 1 (sarcoma) & 3 & Within negative range \\
\hline Rats & Intraperitoneal & 264 & $\begin{array}{l}12 \text { (10 inspecified } \\
2 \text { sarcoma/mesoth }\end{array}$ & ioma) ${ }^{4}$ & $\begin{array}{l}\text { All groups within negative } \\
\text { range }\end{array}$ \\
\hline \multicolumn{6}{|c|}{ JM special purpose fine durable fibres - all sizes } \\
\hline Rats & Intrapleural & 283 & 62 (various) & 9 & $\begin{array}{l}2 \text { negative, } 2 \text { intermediate, } \\
5 \text { positive }\end{array}$ \\
\hline Rats & Intraperitoneal & 1028 & 412 (various) & 22 & $\begin{array}{l}4 \text { negative, } 1 \text { intermediate, } \\
17 \text { positive }\end{array}$ \\
\hline \multicolumn{6}{|c|}{ Owens-Corning fine $\mathrm{E}$-glass fibres } \\
\hline Rats & Intrapleural & 162 & 46 (sarcoma) & 6 & $\begin{array}{l}2 \text { negative, } 2 \text { intermediate, } \\
2 \text { positive }\end{array}$ \\
\hline \multicolumn{6}{|c|}{ Bayer fine special purpose fibres } \\
\hline Rats & Intraperitoneal & 428 & 75 (unspecified) & 10 & $\begin{array}{l}7 \text { negative, } 1 \text { intermediate, } \\
\text { ("slightly durable fibre"), } \\
2 \text { positive ("durable fibre") }\end{array}$ \\
\hline \multicolumn{6}{|c|}{ Control groups } \\
\hline Rats & Intrapleural & 778 & $\begin{array}{l}18 \text { (17 sarcoma, } \\
\text { mesothelioma) }\end{array}$ & 6 & $\begin{array}{l}\text { Highest rate } 17 \text { ex } 615 \\
(2.8 \%)\end{array}$ \\
\hline Various & Intraperitoneal & 846 & 15 (unspecified) & 12 & Highest rate 2 ex $32(6.2 \%)$ \\
\hline Rats & $\begin{array}{l}\text { Untreated } \\
\text { controls }\end{array}$ & 2872 & $\begin{array}{l}8 \text { (3 sarcoma, } \\
5 \text { mesothelioma) }\end{array}$ & 2 & \\
\hline
\end{tabular}

JM: John Manville. 
Appendix VII: glass wool - inhalation studies in the rat

\begin{tabular}{|c|c|c|c|c|c|}
\hline [Ref.] & $\begin{array}{l}\text { Aerosol concentration } \\
\text { fibres } \cdot \mathrm{mL}^{-1}\end{array}$ & Fibre size & $\begin{array}{l}\text { Tumours } \\
\%\end{array}$ & Significance* & $\begin{array}{c}\text { Concentration } \times 10^{5} \text { fibres. } \mathrm{g}^{-1} \\
\text { dry lung tissue }\end{array}$ \\
\hline [116] & 48 & $\begin{array}{l}\text { D: } 69 \%<1 \mu \mathrm{m} \\
\mathrm{L}: 42 \%<10 \mu \mathrm{m}\end{array}$ & 2.2 & NS & 8.3 \\
\hline \multirow[t]{2}{*}{ [104] } & 1436 & $\begin{array}{l}\text { D: } 52 \%<1 \mu \mathrm{m} \\
\text { L: } 72 \% 5.20 \mu \mathrm{m}\end{array}$ & 2.1 & NS & 20 \\
\hline & 323 & $\begin{array}{l}\mathrm{D}: 47 \%<1 \mu \mathrm{m} \\
\mathrm{L}: 58 \% 5.20 \mu \mathrm{m}\end{array}$ & 2.1 & NS & 0.03 \\
\hline [40] & $15 \mathrm{mg} \cdot \mathrm{m}^{-3}$ & $\begin{array}{l}\mathrm{D}: 4.6 \mu \mathrm{m} \\
\mathrm{L}:>20 \mu \mathrm{m}\end{array}$ & 0 & NS & $?$ \\
\hline \multirow[t]{4}{*}{ [111] } & 100 & $\begin{array}{l}\text { D: } 1.2 \mu \mathrm{m} \text { (mean) } \\
\text { L: } 24 \mu \mathrm{m} \text { (mean) }\end{array}$ & 0 & NS & 0.2 \\
\hline & 100 & $\begin{array}{l}\text { D: } 1.1 \mu \mathrm{m} \text { (mean } \\
\mathrm{L}: 20 \mu \mathrm{m} \text { (mean) }\end{array}$ & 0 & NS & 0.01 \\
\hline & 10 & $\begin{array}{l}\text { D: } 1.1 \mu \mathrm{m} \text { (mean) } \\
\mathrm{L}: 20 \mu \mathrm{m} \text { (mean) }\end{array}$ & 0 & NS & 0.001 \\
\hline & 25 & $\begin{array}{l}\mathrm{D}: 3 \mu \mathrm{m} \text { (mean) } \\
\mathrm{L}: 80 \mu \mathrm{m} \text { (mean) }\end{array}$ & 0 & NS & 0.005 \\
\hline \multirow[t]{6}{*}{ [115] } & 232 & $\begin{array}{l}\text { D: } 1.2 \mu \mathrm{m} \text { (mean) } \\
\text { L: } 12.4 \mu \mathrm{m} \text { (mean) }\end{array}$ & 5.9 & NS & 4.1 \\
\hline & 145 & $\begin{array}{l}\text { D: } 1.2 \mu \mathrm{m} \text { (mean) } \\
\mathrm{L}: 12.4 \mu \mathrm{m} \text { (mean) }\end{array}$ & 0.8 & NS & 2.6 \\
\hline & 29 & $\begin{array}{l}\mathrm{D}: 1.2 \mu \mathrm{m} \text { (mean) } \\
\mathrm{L}: 12.4 \mu \mathrm{m} \text { (mean) }\end{array}$ & 0 & NS & 0.3 \\
\hline & 246 & $\begin{array}{l}\text { D: } 0.72 \mu \mathrm{m} \text { (mean) } \\
\mathrm{L}: 11.7 \mu \mathrm{m} \text { (mean) }\end{array}$ & 2.7 & NS & 6.4 \\
\hline & 153 & $\begin{array}{l}\text { D: } 0.72 \mu \mathrm{m} \text { (mean) } \\
\mathrm{L}: 11.7 \mu \mathrm{m} \text { (mean) }\end{array}$ & 7.5 & NS & 3.4 \\
\hline & 41 & D: $0.72 \mu \mathrm{m}$ (mean) & 3.4 & NS & 0.6 \\
\hline
\end{tabular}

*: level of significance of comparison with controls. D: diameter; L: length; NS: not significant.

Appendix VIII: rock wool - inhalation studies in the rat

\begin{tabular}{|c|c|c|c|c|c|}
\hline [Ref.] & $\begin{array}{l}\text { Aerosol concentration } \\
\text { fibres } \cdot \mathrm{mL}^{-1}\end{array}$ & Fibre size & $\begin{array}{c}\text { Tumours } \\
\%\end{array}$ & Significance* & Comments \\
\hline [116] & 41 & $\begin{array}{l}\text { D: } 23 \%<1 \mu \mathrm{m} \\
\text { L: } 60 \%>10 \mu \mathrm{m}\end{array}$ & 0 & NS & \\
\hline$[104]$ & 214 & $\begin{array}{l}\text { D: } 58 \%<1 \mu \mathrm{m} \\
\text { L: } 71 \% 5-20 \mu \mathrm{m}\end{array}$ & 4 & NS & 20 \\
\hline$[100]$ & $\begin{array}{r}225 \\
150 \\
25\end{array}$ & & $\begin{array}{l}4.2 \\
3.4 \\
3.4\end{array}$ & $\begin{array}{l}\text { NS } \\
\text { NS } \\
\text { NS }\end{array}$ & $\begin{array}{c}0.03 \\
\text { Lung fibrosis } \\
\text { Lung fibrosis } \\
\text { No lung fibrosis }\end{array}$ \\
\hline
\end{tabular}

For abbreviations see legend to Appendix VII. *: level of significance of comparison with controls.

Appendix IX: slag wool - inhalation studies in the rat

\begin{tabular}{|c|c|c|c|c|c|}
\hline [Ref.] & $\begin{array}{l}\text { Aerosol concentration } \\
\text { fibres } \cdot \mathrm{mL}^{-1}\end{array}$ & Fibre size & $\begin{array}{c}\text { Tumours } \\
\%\end{array}$ & Significance* & Comments \\
\hline \multirow[t]{2}{*}{ [111] } & 200 & $\begin{array}{l}\mathrm{D}: 0.9 \mu \mathrm{m} \text { (mean) } \\
\mathrm{L}: 22 \mu \mathrm{m} \text { (mean) }\end{array}$ & 0 & NS & Lung fibrosis $(9 / 55)$ \\
\hline & 200 & $\begin{array}{l}\mathrm{D}: 0.9 \mu \mathrm{m} \text { (mean) } \\
\mathrm{L}: 22 \mu \mathrm{m} \text { (mean) }\end{array}$ & 0 & NS & No lung fibrosis \\
\hline \multirow[t]{3}{*}[100]{} & 225 & & 4.2 & NS & No lung fibrosis \\
\hline & 150 & & 0 & NS & No lung fibrosis \\
\hline & 25 & & 1.6 & Ns & No lung fibrosis \\
\hline
\end{tabular}

For abbreviations see legend to Appendix VII. *: level of significance of comparison with controls. 


\section{References}

1. IARC. IARC Monographs on the Evaluation of the Carcinogenic Risk of Chemicals to Humans. Vol. 43. Man-made Mineral Fibers and Radon. Lyon, International Agency for Research on Cancer, 1988.

2. Timbrell. V The inhalation of fibrous dusts. Ann NY Acad Sci 1965; 132: 255-273.

3. National Research Council of Canada (NRCC) Associate Committee on Scientific Criteria for Environmental Quality. Effects of inhaled particles on human health: influence of particle size and shape. Publications NRCC/CNRC, Ottawa, Canada, 1982.

4. McDonald JC, Armstrong B, Case B, et al. Mesothelioma and asbestos fiber type: evidence from lung tissue analyses. Cancer 1989; 63: 1544-1547.

5. Bignon J, Saracci R, Touray JC. Biopersistence of respirable synthetic fibers and minerals. Environ Health Persp 1994; 102 (Suppl. 5).

6. Sebastien P. Pulmonary deposition and clearance of airborne mineral fibers. In: Liddell D, Miller K, eds. Mineral Fibers and Health. Boca Raton, Boston, CRC Press, 1991; pp. 229-248.

7. McDonald JC, McDonald A. Epidemiology of mesothelioma. In: Liddell D, Miller K, eds. Mineral Fibers and Health. Boca Raton, Boston, CRC Press, 1991; pp. 147168.

8. Stanton MF, Layard M, Tegeris A, et al. Relation of particle dimension to carcinogenicity in amphibole asbestos and other fibrous minerals. J Nat Cancer Inst 1981; 67: 965-975.

9. Pott F. Animal experiments on biological effects of mineral fibres. In: Wagner JC, ed. Biological Effects of Mineral Fibers. Lyon, France, IARC Scientific Publications, 1980; 30: pp. 261-269.

10. Parkes WR. In: Occupational Lung Disorders. Second Edn. 1982; pp. 134-174.

11. Pezerat H, Zalma R, Guignard J, Jaurand MC. Production of oxygen radicals by the reduction of oxygen arising from the surface activity of mineral fibers. In: Bignon J, Peto J, Saracci R, eds. Nonoccupational Exposure to Mineral Fibers. Lyon, IARC, 1989; 90: 100-111.

12. Gibbs AR, Stephens M, Griffiths DM, Blight BJN, Pooley FD. Fibre distribution in the lungs and pleura of subjects with asbestos-related diffuse pleural fibrosis. Br J Ind Med 1991; 48: 762-770.

13. Boutin C, Dumortier P, Rey F, Viallat JR, De Vuyst P. Black spots concentrate oncogenic asbestos fibers in the parietal pleura. Am Rev Respir Crit Care Med 1995; (in press).

14. Pathology of Occupational Lung Disease. In: Churg A, Green FHY, eds. New York - Tokyo, Igaku-Shoin, 1987; pp. 213-234.

15. Wagner JC, Newhouse ML, Corrin B, Rossiter CER, Griffiths DM. Correlation between fibre content of the lung and disease in east London asbestos factory workers. $\mathrm{Br} \mathrm{J}$ Ind Med 1988; 45: 305-308.

16. Roggli VL, Greenberg SD, Pratt PhC. Pathology of asbestosassociated diseases. Boston/Toronto/London, Little, Brown and Co., 1992; pp. 299-345.

17. Becklake M, Case B. Fiber burden and asbestos-related lung disease: determinants of dose response relationship. Am J Respir Crit Care Med 1994; 150: 1488-1492.

18. Jones JSP, Smith PG, Pooley FD, et al. The consequences of exposure to asbestos dust in a wartime gas-mask factory. In: Wagner JC, ed. Biological Effects of Mineral Fibers.
Lyon, France, IARC Scientific Publications, 1980; 30: pp. 637-653.

19. Craighead JE, Abraham JL, Churg A, et al. The pathology of asbestos-associated diseases of the lungs and pleural cavities: diagnostic criteria and proposed grading schema. Arch Pathol Lab Med 1982; 106: 544-596.

20. Hammond EC, Selikoff IJ, Seidman H. Asbestos exposure, cigarette smoking and death rates. In: Selikoff IJ, Hammond EC, eds. Health Hazards of Asbestos Exposure. Ann NY Acad Sci 1979; 330: 473-490.

21. Mossman B, Craighead J. Mcchanisms of asbcstos-associated bronchogenic carcinoma. In: Antman K, Aisner J, eds. Asbestos-related Malignancy. London, Grune et Stratton, 1987; pp. 137-150.

22. Berry G, Newhouse ML, Antonis P. Combined effects of asbestos and smoking on mortality from lung cancer and mesothelioma in factory workers. Br J Ind Med 1985; 42: $12-18$.

23. Kipen H, Lilis R, Suzuki Y, Valciukas J, Selikoff IJ. Pulmonary fibrosis in asbestos insulation workers with lung cancer: a radiological and histopathological evaluation. Brit J Ind Med 1987; 44: 96-100.

24. Hughes JH, Weill H. Asbestosis as a precursor of asbestosrelated lung cancer: results of a prospective mortality study. Brit J Ind Med 1991; 48: 229-233.

25. Wilkinson P, Hansell D, Janssens J, et al. Is lung cancer associated with asbestos exposure when there are no small opacities on the chest radiograph? Lancet 1995 ; 345 : 1074 1078.

26. Nomenclature Committee of TIMA Inc. Man-made Vitreous Fibers: Nomenclature, Chemical and Physical Properties. In: Eastes W, ed. Stamford, CT, Owens-Corning Fiberglass, 1991.

27. IPCS-WHO. Environmental Health Criteria. 77: Manmade Mineral Fibers. Geneva, World Health Organization, 1988.

28. Official Journal of the European Communities (90/394/EEC; 196/1). 1990; 26.7.1990.

29. Öhberg I. Technological development of the mineral wool industry in Europe. Ann Occup Hyg 1987; 31: 529545.

30. Klingholz R. Technology and production of man-made mineral fibers. Ann Occup Hyg 1977; 20: 153-159.

31. Lockey J, Wiese N. Health effects of synthetic vitreous fibers. In: G. Epler, ed. Clinics in Chest Medicine. Occupational Lung Diseases. Philadelphia, Saunders, 1992; pp. 329-338.

32. Fallentin B, Kamstrup O. Simulation of past exposure in slag wool production. Ann Occup Hyg 1993; 37: 419433.

33. Kilburn KH, Warshaw RH. Difficulties of attribution of effect in workers exposed to fiberglass and asbestos. Am J Ind Med 1991; 20: 645-751.

34. Marsh GM, Enterline PE, Stone RA, Henderson VL. Mortality among a cohort of US man-made mineral fiber workers: 1985 follow-up. J Occup Med 1990; 32: 594604.

35. WHO/Euro. Technical committee for monitoring and evaluating MMMF: the WHO/Euro man-made mineral fiber reference scheme. Scand J Work Environ Health 1985; 11: 123-129.

36. Crawford NP, Kello D, Jarvisalo JO. Monitoring and evaluating man-made mineral fibers: work of a WHO/ Euro reference scheme. Ann Occup Hyg 1987; 31: 557565.

37. Young J. Properties, applications and manufacture of man-made mineral fibers. In: Liddell D, Miller K, eds. 
Mineral Fibers and Health. Boca Raton, CRC Press, 1991; pp. 37-55.

38. Cherrie J, Dodgson J, Groat S, MacLaren W. Environmental surveys in the European man-made mineral fibre production industry. Scand J Work Environ Health 1986; 12: $18-25$.

39. WHO/Euro reports and studies. 81. Biological effects of man-made mineral fibers. Report of a WHO meeting held in Copenhagen, Denmark, 20-22 April, 1982.

40. Searl A. A review of the durability of inhaled fibers and options for the design of safer fibers. Ann Occup Hyg 1994; Vol. 38: pp. 839-855.

41. Scholze M, Conradt R. An in vitro study of the chemical durability of siliceous fibers. Ann Occup Hyg 1987; 31: 683-692.

42. Bauer JF, Law BD, Hesterberg TW. Dual pH durability studies of man-made vitreous fibers (MMVF). Environ Health Persp 1994; 102 (Suppl. 5): 61-66.

43. Law BD, Bunn WB, Hesterberg TW. Solubility of polymeric and man-made vitreous fibers in Gamble's solution. Inhal Toxicol 1990; 2: 321-339.

44. Jaurand MC. In vitro assessment of biopersistence using mammalian cell systems. Environ Health Persp 1994; 102 (Suppl. 5): 55-59.

45. Sebastien P, Vergnon JM, Blanchard O, Wastiaux A, Emonot A. Durability of ceramic fibres in the human lung: preliminary results. Ann Occup Hyg 1994; 38 (Suppl. 1): 723730.

46. Morgan A, Holmes A. Solubility of rock wool fibres in vivo and the formation of pseudo-asbestos bodies. Ann Occup Hyg 1984; 28: 307-314.

47. Bellmann B, Muhle H, Pott F, König H, Klöppel H, Spurny K. Persistence of man -made mineral fibres (MMMF) and asbestos in rat lungs. Ann Occup Hyg 1987; 31: 693-709.

48. Muhle M, Bellman B, Pott F. Comparative investigation of the biodurability of mineral fibers in the rat lung. Environ Health Persp 1994; 102 (Suppl. 5): 163-168.

49. Musselman RP, Miller WC, Eastes W, et al. Biopersistences of man-made vitreous fibers and crocidolite fibers in rat lungs following short-term exposures. Environ Health Persp 1994; 102 (Suppl. 5): 139-144.

50. Morgan A, Holmes A. Solubility of asbestos and man-made mineral fibers in vitro and in vivo: its significance in lung disease. Environ Res 1986; 39: 475-484.

51. Yamato H, Hori H, Tanaka I, Higashi T, Morimoto Y, Kido M. Retention and clearance of inhaled ceramic fibres in rat lungs and development of a dissolution model. Occup Environ Med 1994; 51: 275-280.

52. Morgan A, Holmes A, Davison W. Clearance of sized glass fibers from the rat lung and their solubility in vivo. Ann Occup Hyg 1982; 25: 317.

53. Holmes A, Morgan A, Davidson W. Formation of pseudoasbestos bodies on sized glass fibers in the hamster lung. Ann Occup Hyg 1983; 27: 301-313.

54. Bernstein DM, Drew RT, Schidlovsky G, Kuschner M. The pathogenicity of MMMF in contrast to natural fibres. In: Biological Effect of Man-made Mineral Fibres. Vol. 2. WHO/IARC Conference, Copenhagen, 1984; 169.

55. Lehuédé $P$, de Meringo A. SEM-EDS analysis, of glass fibers corroded in physiological solutions by dynamic tests with variable flow rates. Environ Health Persp 1994; 102 (Suppl 5): 73-75.

56. Morgan A. In vivo evaluation of chemical biopersistance of man-made mineral fibers. Environ Health Persp 1994; 102 (Suppl. 5): 127-131.
57. LeBouffant L, Daniel H, Henin JP, et al. Experimental study on long-term effects of inhaled MMMF on the lungs of rats. Ann Occup Hyg 1987; 31: 764-790.

58. McDonald JC, Case BW, Enterline PE, et al. Lung dust analysis in the assessment of past exposure of man-made mineral fiber workers. Ann Occup Hyg 1990; 34: 427441.

59. Roggli VL. Rare pneumoconiosis: metalloconiosis. In: Saldana MS, ed. Pathology of Pulmonary Disease. Philadelphia, J.B. Lippincott 1994; pp. 411-422.

60. Tuomi T, Huuskonen MS, Tammilehto L, Vanhala E, Virtamo M. Occupational exposure to asbestos as evaluated from work histories and analysis of lung tissues from patients with mesothelioma. Br J Ind Med 1991; 48: 48-52.

61. Gaudichet A, Janson X, Monchaux G, et al. Assessment by analytical microscopy of the total lung fibre burden in mesothelioma patients matched with four other pathological series. In: Dogson J, et al. eds. Inhaled Particles. VI. Oxford, Pergamon, 1988; pp. 213-223.

62. McDonald JC, Armstrong B, Case B, et al. Mesothelioma and asbestos fiber type: evidence from lung tissue analyses. Cancer 1989; 63: 1544-1547.

63. Sébastien $\mathrm{P}, \mathrm{McD}$ onald JC, McDonald AD, Case B, Harley R. Respiratory cancer in chrysotile textile and mining industries: exposure inferences from lung analysis. Br J Ind Med 1989; 46: 180-187.

64. Esmen N, Corn M, Hammad Y, Whittier D, Kotsko N. Summary of measurements of employee exposure to airborne dust and fiber in sixteen facilities producing manmade mineral fibers. Am Indust Hyg Assoc J 1979; 40: 108.

65. Davies L, Cherrie JW. Airborne fibre concentrations in a glass continuous filament factory. Ann Occup Hyg 1992; 36: 609-627.

66. Hori H, Higashi T, Fujino A, Yamato H, Ishimatsu S, Oyabu T. Measurement of airborne ceramic fibres in manufacturing and processing factories. Ann Occup Hyg 1993; 37: 623-629.

67. Jaffrey SAMT. Levels of airborne man-made mineral fibers in UK dwellings. I. Fibre levels during and after installation of insulation. Atmos Environ 1990; 24A: 133141.

68. Van der Wal JF, Ebens R, Tempelman J. Man-made mineral fibres in homes caused by thermal insulation. Atmos Environ 1987; 21: 13-19.

69. Schneider T, Husemoen T, Olsen E, Christensen V, Kamstrup O. Airborne fibre concentration during standardized building insulation with bonded man-made vitreous fibre insulation material having different nominal diameters and oil content. Ann Occup Hyg 1993; 37: 631644.

70. Fowler DP, Balzer JL, Cooper WC. Exposure of insulation workers to airborne fibrous glass. Am Ind Hyg Assoc $J$ 1971; 32: 86.

71. Gaudichet A, Petit G, Billon-Galland MA, Dufour G. Levels of atmospheric pollution by man-made mineral fibres in buildings. In: Bignon J, Peto J, Saracci R, eds. Nonoccupational exposure to mineral fibres. Lyon, IARC Scientific Publications 90, 1989; pp. 291-298.

72. Schneider T, Nielsen O, Bredsdorff P, Linde P. Dust in buildings with man-made mineral fiber ceiling boards. Scand J Work Environ Health 1990; 16: 434-439.

73. Jaffrey SAMT, Rood AP, Llewellyn JW, Wilson AJ. Levels of airborne man-made mineral fibres in UK dwellings. II. Fibre levels during and after some disturbance of loft insulation. Atmos Environ 1990; 24A: 143-146. 
74. Dodgson J, Cherrie J, Groat S. Estimates of past exposure to respirable man-made mineral fibers in the European insulation wool industry. Ann Occup Hyg 1987; 31: 567-582.

75. Cherrie J, Krantz S, Schneider T, Ohberg I, Karmstrup O, Linander W. An experimental simulation of an early rock wool/slag wool production process. Ann Occup Hyg 1987; 31: 583-593.

76. Jaurand MC. Mechanisms of fibre genotoxicity. In: Brown RC, Hoskins JA, Johnson NF, eds. Mechanisms in Fibre Carcinogenesis. New York, Plenium Press 1991; pp. 287 306.

77. Achard-Ellouk S, Jaurand MC. Review on animal/in vitro data on biological effects of man made fibers. Environ Health Persp 1994; 102 (Suppl. 2): 47-61.

78. Hesterberg TW, Hart GA, Bunn WB. In vitro toxicology of fibers: mechanistic studies and possible use for screening assays. In: Warheit DB, ed. Fiber Toxicology. San Diego, Academic Press Inc., 1993; pp. 139-170.

79. Forget G, Lacroix MJ, Brown RC, Evans PH, Sirois P. Response of perfused alveolar macrophages to glass fibers: effect of exposure duration and fiber length. Environ Res 1986; 39: 124-135.

80. Gormley IP, Brown GM, Cowie H, Wright A, Davis JMG. The effects of fiber length on the in vitro cytotoxicity of asbestos samples in three different assay systems. In: Beck EG, Bignon J, eds. In vitro effects of mineral dusts. Berlin, NATO ASI Series, 1985; G3: pp. 397-404.

81. Brown GM, Cowie H, Davis JMG, Donaldson K. In vitro assays for detecting carcinogenic mineral fibres: a comparison of two assays and the role of fibre size. Carcinogenesis 1986; 7: 1971-1974.

82. Tilkes F, Beck EG. Macrophage functions after exposure to mineral fibers. Environ Health Persp 1983; 51: 67-72.

83. Pickrell JA, Hill JO. Carpenter RL, Hahn FF, Rebar AH. In vitro and in vivo response after exposure to man-made mineral and asbestos insulation fibers. Am Ind Hyg Assoc J 1983; 44: 557-561.

84. Oshimura M, Hesterberg TW, Tsutsui T, Barrett JC. Correlation of asbestos-induced cytogenetic effects with cell transformation of Syrian hamster embryo cells in culture. Cancer Res 1984; 44: 5017-5022.

85. Hesterberg TW, Butterick CJ, Oshimura M, Brody AR, Barrett JC. Role of phagocytosis in Syrian hamster cell transformation and cytogenetic effects induced by asbestos and short and long glass fibers. Cancer Res 1986; 46: 5795-5802.

86. Sincock AM, Delhanty JDA, Casey G. A comparison of the cytogenetic response to asbestos and glass fibre in Chinese hamster and human cell lines. Mutat Res 1982; 101: 257-268.

87. Casey G. Sister-chromatid exchange and cell kinetics in CHO-K1 cells, human fibroblasts and lymphoblastoid cells exposed in vitro to asbestos and glass fibre. Mutat Res 1983; 116: 369-377.

88. Brown RC, Chamberlain M, Davies R, Gaffen J, Skidmore JW. In vitro biological effects of glass fibers. J Environ Pathol Toxicol 1979; 2: 1369-1383.

89. Woodworth CD, Mossman BT, Craighead JE. Induction of squamous metaplasia in organ cultures of hamster trachea by naturally occurring and synthetic fibers. Cancer Res 1983; 43: 4906-4912.

90. Hesterberg TW, Barrett JC. Dependence of asbestos-and mineral dust-induced transformation of mammalian cells in culture on fiber dimension. Cancer Res 1984; 44: 2170-2180.

91. Mikalsen SO, Rivedal E, Sanner T. Morphological transformation of Syrian hamster embryo cells induced by mineral fibres and the alleged enhancement of benzo(a)-pyrene. Carcinogenesis 1988; 9: 891-899.

92. Fischer AB. Induction of sister chromatid exchanges by fibrous dusts alone and in combination with other xenobiotics in Chinese hamster cells. In: Mossman BT, Begin RO, eds. Effects of Mineral Dusts on Cells. Berlin, NATO ASI Series, 1989; H30: pp. 149-156.

93. Linnainmaa K, Pelin-Enlund K, Jantunen K, et al. Chromosomal damage and gap junctional intercellular communication in mesothelioma cell lines and cultured human primary mesothelial cells treated with MMMF, asbestos and erionite. In: Brown RC, Hoskins JA, Johnson NF, eds. Mechanisms in Fibre Carcinogenesis. New York, Plenum Press, 1991; pp. 327-334.

94. Hart GA, Newman MM, Bunn WB, Hesterberg TW. Cytotoxicity of refractory ceramic fibres to Chinese hamster ovary cells in culture. Toxic In Vitro 1992; 6: 317-326.

95. Hansen K, Mossman BT. Generation of superoxide $\left(\mathrm{O}_{2}^{-}\right)$ from alveolar macrophages exposed to asbestiform and nonfibrous particles. Cancer Res 1987; 47: 1681-1686.

96. Maples KR, Johnson NF. Fiber-induced hydroxyl radical formation: correlation with mesothelioma induction in rats and humans. Carcinogenesis 1992; 13: 2035-2039.

97. Leanderson P, Tagesson C. Hydrogen peroxide release and hydroxyl radical formation in mixtures containing mineral fibres and human neutrophils. Br J Ind Med 1992; 49: 745-749.

98. Wheeler C. Exposure to man-made mineral fibers: a summary of current animal data. Toxic Ind Health 1990; 6 (2): 293-307.

99. Lippmann M. Man made mineral fibers (MMMF): human exposure and health risk assessment. Toxic Ind Health 1990; 6: 225-246.

100. Rossiter C, Chase J. Statistical analysis of results of carcinogenicity studies of synthetic vitreous fibres at Research and Consulting Company, Geneva. Ann Occup Hyg (in press).

101. Bernstein DM. Evaluation of the oncogenic potential of man-made vitreous fibers: the inhalation model. Ann Occup Hyg (in press).

102. Lehnert B, Oberdörster G. Fiber retention and pathogenesis in the context of "particle overload". In: Warheit D, ed. Fiber Toxicology. New York, Academic Press 1993; pp. 373-381.

103. Stanton MF, Layard M, Tegeris A, Miller E, May M, Kent E. Carcinogenicity of fibrous glass: pleural response in the rat in relation to fibre dimension. J Nat Cancer Inst 1981; 58: 587-603.

104. Wagner JC, Berry G, Hill RJ, Munday DE, Skidmore JW. Animal experiments with MMVF. In: Biological Effects of Mineral Fibres. Vol. 2. Copenhagen, WHO, 1984; pp. 209-233.

105. Pott F, Ziem V, Reiffer FJ, Huth F, Ernst H, Mohr U. Carcinogenicity studies on fibres, metal compounds, and some other dusts in rats. Exp Path 1987; 32: 129-152.

106.Pott F, Roller M, Ziem U, et al. Carcinogenicity studies on natural and man-made fibres with the intraperitoneal test in rats. In: Bignon J, Peto J, Saracci R, eds. Nonoccupational Exposure to Mineral Fibres. Lyon, International Agency for Research on Cancer 1989; pp 173-179. 
107. Pott F, Schlipkoter HW, Ziem U, Spurny K, Huth F. New results from implantation experiments with mineral fibres. In: Biological Effects of Mineral Fibres. 1984, Vol. 2. Copenhagen, WHO, pp. 286-302.

108. Pott F, Roller M, Rippe RM, Germann PG, Bellmann B. Tumours by the intraperitoneal and intrapleural routes and their significance for the classification of mineral fibres. In: Brown RC, Hoskins JA, Johnson HF, eds. Mechanisms of Fibre Carcinogenesis. Proceedings of a NATO advanced research workshop. Plenum Press, 1991.

109. Rossiter GE. Fibres of intermediate durability: animal evidence of critical fibre diameter for carcinogenic potential. In: Gibbs GW, Dunnigan J, Kido M, Higashi T, eds. Health Risks from Exposure to Mineral Fibres. 1993; pp. 334-347.

110. Brochard P, Pairon JC, Bignon J. The occupational physician's point of view: the model of man-made vitreous fibers. Environ Health Persp 1994; 102 (5): 31-36.

111. Smith DM, Ortiz LW, Archuleta RF, Johnson NF. Longterm health effects in hamsters and rats exposed chronically to man-made vitreous fibres. Ann Occup Hyg 1987; 31: 731-754.

112. Maltoni C, Minardi F. Recent results of carcinogenicity biosssays of fibres and other particulate matters. In: Bignon J, Peto J, Saracci R, eds. Nonoccupational exposure to mineral fibres. Lyon, International Agency for Research on Cancer, 1989; pp. 46-53.

113. Pott F, Roller M, Kamino K, Bellman B. Significance of durability of mineral fibers and crocidolite fibers in rat lungs following short-term exposures. Environ Health Persp 1994; 102 (Suppl. 5): 145-150.

114. WHO. Validity of methods for assessing the carcinogenicity of man-made fibres. Executive summary of a WHO consultation, 19-20 May 1992. Copenhagen, World Health Organization.

115. Bunn WB, Bender JR, Hesterberg TW, Chase GR, Konzen JL. Recent studies of man-made vitreous fibers. J Occup Med 1993; 35: 101-113.

116. Le Bouffant L, Daniel H, Henin JP, et al. Experimental study on long-term effects of inhaled MMMF on the lungs of rats. Ann Occup Hyg 1987; 31: 765-790.

117. Mitchell RI, Donofrio DJ, Moorman WJ. Chronic inhalation toxicity of fibrous glass in rats and monkeys. $\mathrm{J} \mathrm{Am}$ Coll Toxicol 1986; 5: 545-575.

118. Peto J. Fibre carcinogenesis and environmental hazards. In: Bignon J, Peto J, Saracci R, eds. Nonoccupational Exposure to Mineral Fibers. Lyon, ARC Scientific Publications, no. 90, 1989; pp. 457-470.

119. Nasr A, Ditchek T, Scholtens P. The prevalence of radiographic abnormalities in the chests of fiberglass workers. J Occup Med 1971; 13: 371-376.

120. Hill JW, Rossiter CE, Foden DW. A pilot respiratory morbidity study of workers in a MMMF plant in the United Kingdom. In: Biological Effects of Man-made Mineral Fibres. Proceedings of a WHO/IARC conference, Copenhagen, Denmark, 20-22 April 1982, Copenhagen World Health Organization, Regional Office for Europe, 1984; Vol. 1; pp. 413-426.

121. Wright G. Airbone fibrous glass particles: chest roentgenograms of persons with prolonged exposure. Arch Environ Health 1968; 16: 175-181.

122. Weill H, Hughes J, Hammad Y, Glindmeyer H, Sharon G, Jones R. Respiratory health in workers exposed to man-made vitreous fibers. Am Rev Respir Dis 1983; 128: 104-112.
123. Hughes J, Jones R, Glindmeyer H, Hammad Y, Weill H. Follow-up study of workers exposed to man-made mineral fibres. Br J Ind Med 1993; 50: 658-667.

124. Castellan R, Sanderson W, Petersen M. Prevalence of radiographic appearance of pneumoconiosis in an unexpected blue collar population. Am Rev Respir Dis 1985; 131: 684686.

125. Dick J, Morgan K, Muir D, Reger R, Sargent N. The significance of irregular opacities on the chest roentgenogram. Chest 1992; 102: 251-260.

126. Gevenois PA, Pichot E, Dargent F, Dedeire S, Vande Weyer R, De Vuyst P. Low-grade coal worker's pneumoconiosis: comparison of CT and chest radiograph. Acta Radiologica 1994; 35: 351-356.

127. Kilburn K, Powers D, Warshaw R. Pulmonary effects of exposure to fine fibreglass: irregular opacities and small airways obstruction. Br J Ind Med 1992; 49: 714-720.

128. Philippou S, Morgenroth K. Glasfaserpneumokoniose? Licht und rasterlektronenmikroskopische Untersuchungen unter Einsatz der energie dispersiven Röntgenmikroanalyse. Pathologe 1992; 13: 20-24.

129. Rogan W, Gladen B, Ragan N. US prevalence of occupational pleural thickening: a look at chest $\mathrm{X}$-rays from the first national health and nutrition examination survey. Ann J Epidemiol 1987; 126: 893-900.

130. Lemasters G, Lockey J, Rice C, et al. Radiographic changes among workers manufacturing refractory ceramic fibre and products. Ann Occup Hyg 1994; 38 (Suppl. 1): 745-751.

131. Moulin JJ, Pham QT, Mur JM, et al. Enquête épidémiologiques dans deux usines productrices de fibres minérales artificielles. II. Symptômes respiratoires et fonction pulmonaire. Arch Mal Prof Med Trav Secur Soc 1987; 48: 7-16.

132. Chiazze L, Watkins D, Fryar C. A case-control study of malignant and nonmalignant respiratory disease among employers of a fibreglass manufacturing facility. $\mathrm{Br} J$ Ind Med 1992; 49: 326-331.

133. Trethowan W, Burge PS, Rossiter CE, Harrington JM, Calvert I. A study of the respiratory health of employers in seven European ceramic fibre manufacturing plants. Occup Environ Med 1995; 52: 97-104.

134. De Vuyst P, Symoens F, Saint Remy P, Jacobovitz D, Vande Weyer R, Nolard N. Alvéolite allergique extrinsèque chez un ouvrier de fabrication de fibres de verre. Rev Fr Mal Respir 1992; Suppl. 3: 150.

135. Simonato L, Fletcher AC, Cherrie JW, Andersen A, Bertazzi P. The International Agency for Research on Cancer historical cohort study of MMMF production workers in seven European countries: extension of the follow-up. Ann Occup Hyg 1987; 31: 603-623.

136. Boffetta P, Saracci R, Andersen A, et al. Lung cancer mortality among workers in the European production of manmade mineral fibers: a Poisson regression analysis. Scand J Work Environ Health 1992; 18: 279-286.

137. Shannon HS, Jamieson E, Julian JA, Muir DCF. Mortality of glass filament (textile) workers. Br J Ind Med 1990; 47: $533-536$.

138. Teppo L, Kojonen E. Mortality and cancer risk among workers exposed to man-made mineral fibers in Finland. Scand J Work Environ Health 1986; Suppl. 1: 61-64.

139. Westerholm P, Bolander AM. Mortality and cancer incidence in the man-made mineral fiber industry in Sweden. Scand $J$ Work Environ Health 1986; Suppl. 2: 78-84.

140. Doll R. Symposium on MMMF, Copenhagen, October 1986: overview and conclusions. Ann Occup Hyg 1987; 31: 805-819. 
141. Miettinen OS, Rossiter CE. Man-made mineral fibers and lung cancer. Scand J Work Environ Health 1990; 16: 221-231.

142. Brown RC, Davis JMG, Douglas D, et al. Carcinogenicity of the insulation wools: reassessement of the IARC evaluation. Reg Tox Pharm 1991; 14: 12-23.

143. Hughes J, Weill H. Asbestos and man made mineral fibers. In: Samet J, ed. Epidemiology of Lung Cancer. Lung Biology in Health and Disease. 1994; pp. 185-205.

144. Breslow ME, Day ME. Statistical Methods in Cancer Research. Vol. II. Design and analysis of cohort studies. Lyon, France, IARC Scientific Publications, No. 82, 1987.

145. Boffetta P, Saracci R, Andersen A, et al. The IARC historical cohort study of manmade mineral fiber production workers in seven European countries: preliminary results of an extension of the mortality follow-up. 10th International Symposium Epidemiology in Occupational Health (ISEOH), 1994; Como, Italy, Abstract.

146. Enterline PE, Marsh GM, Henderson V, Callahan C. Mortality update of a cohort of US man-made mineral fibre workers. Ann Occup Hyg 1987; 31: 625-656.

147. Enterline P. Role of man-made mineral fibres in the causation of cancer. Br J Ind Med 1990; 47: 145-146 (Editorial) and 646-647 (Letter).

148. Wong O, Foliart D, Trent LS. A case-control study of lung cancer in a cohort of workers potentially exposed to slag wool fibres. Br J Ind Med 1991; 48: 818-824.

149. Kjuus H, Skjaerven, Langard, Lien JT, Aamodt T. A case-referent study of lung cancer, occupational exposures and smoking. Scand J Work Environ Health 1986; 12: 193-202.

150. Chiazze L, Watkins DK, Fryar C, Kozono J. A case-control study of malignant and nonmalignant respiratory disease among employees of a fibreglass manufacturing facility. II. Exposure assessment. Br J Ind Med 1993; 50: 717-725.

151. Iwatsubo Y, Pairon JC, Archambault C, et al. Pleural mesothelioma and exposure to mineral fibers. 24th Congress of the International Commission on Occupational Health. Nice, France, September 26-October 1, 1993.

152. De Vuyst P. Biopersistence of respirable synthetic fibers and minerals: the point of view of the chest physician. Environ Health Persp 1994; 102 (Suppl. 5): 7-9.

153. Beck EG, Holt PF, Manojlovic N. Comparison of effects on macrophage cultures of glass fibre, glass powder, and chrysolite asbestos. Br J Ind Med 1972; 29: 280-286.

154. Richards RJ, Jacoby F. Light microscope studies on the effects of chrysolite asbestos and fiber glass on the morphology and reticulin formation in cultured lung fibroblasts. Environ Res 1976; 11: 112-121.

155. Davies R. The effect of mineral fibres on macrophages. In: Wagner JC, ed. Biological Effects of Mineral Fibres. Lyon, IARC Sci Publ, No. 30, 1980; 1: pp. 419-425.
156. Lipkin LE. Cellular effects of asbestos and other fibers: correlations with in vivo induction of pleural sarcoma. Environ Health Persp 1980; 34: 91-102.

157. Tilkes F, Beck EG. Comparison of length-dependent cytotoxicity of inhalable asbestos and man-made mineral fibres. In: Wagner JC, ed. Biological Effects of Mineral Fibres. Lyon, IARC Sci Publ, 1980; 30; 475-483.

158. Haugen A, Schafer PW, Lechner JF, Stoner GD, Trump BF, Harris CC. Cellular ingestion, toxic effects, and lesions observed in human bronchial epithelial tissue and cells cultured with asbestos and glass fibers. Int $J$ Cancer 1982; 30: 265-272.

159. Tilkes F, Beck EG. Influence of well-defined mineral fibers on proliferating cells. Environ Health Persp 1983; 51: 275-279.

160. Ririe DG, Hesterberg TW, Barrett JC, Nettesheim P. Toxicity of asbestos and glass fibers for rat tracheal epithelial cells in culture. In: Beck EG, Bignon J, eds. In Vitro Effects of Mineral Dusts. Berlin, NATO ASI Series, 1985; G3: pp. 177-184.

161. Pelin K, Husgafvel-Pursiainen K, Vallas M, Vanhala E, Linnainmaa K. Cytotoxicity and anaphase aberrations induced by mineral fibres in cultured human mesothelial cells. Toxic in Vitro 1992; 6: 445-450.

162. Wright A, Gormley IP, Collings PL, Davis JMG. The cytotoxicities of asbestos and other fibrous dusts. In: Brown RC, Gormley IP, Chamberlain M, Davies R, eds. In Vitro Effects of Mineral Dusts. London, Academic Press, 1980; pp. 25-31.

163. Aalto M, Heppleston AG. Fibrogenesis by mineral fibres: an in vivo study of the roles of the macrophage and fibre length. Br J Exp Path 1984; 65: 91-99.

164. Marsh JP, Jean L, Mossman BT. Asbestos and fibrous glass induce biosynthesis of polyamines in tracheobronchial epithelial cells in vitro. In: Beck EG, Bignon J, eds. In Vitro Effects of Mineral Dusts. NATO ASI Series, Berlin, Springer Verlag, 1985; G3: pp. 305-311.

165. Adachi S, Kawamura K, Yoshida S, Takemoto K. Oxidative damage on DNA induced by asbestos and man-made fibers in vitro. Int Arch Occup Environ Health 1992; 63: 553-557.

166. Sincock AM, Seabright M. Induction of chromosome changes in Chinese hamster cells by exposure to asbestos fibres. Nature 1975; 257: 56-58.

167. Sincock AM. Preliminary studies of the in vitro cellular effects of asbestos and fine glass dusts. In: Origins of Human Cancer. Cold Spring Harbor, New York, Cold Spring Harbor Laboratory Press, 1977; pp. 941-954.

168. Chamberlain M, Tarmy EM. Asbestos and glass fibres in bacterial mutation tests. Mutat Res 1977; 43: 159-164.

169. Poole A, Brown RC, Rood AP. The in vitro activities of a highly carcinogenic mineral fibre potassium octatitanate. Br J Exp Path 1986; 67: 289-296. 